2018-07

Mixtures of tritiated water, zinc and

dissolved organic carbon: Assessing

interactive bioaccumulation and

genotoxic effects in marine mussels,

Mytilus galloprovincialis

\title{
Pearson, HBC
}

http://hdl.handle.net/10026.1/12351

10.1016/j.jenvrad.2017.12.018

Journal of Environmental Radioactivity

Elsevier

All content in PEARL is protected by copyright law. Author manuscripts are made available in accordance with publisher policies. Please cite only the published version using the details provided on the item record or document. In the absence of an open licence (e.g. Creative Commons), permissions for further reuse of content should be sought from the publisher or author. 
Journal of Environmental Radioactivity 187 (2018) 133-143

Mixtures of tritiated water, zinc and dissolved organic carbon: assessing interactive bioaccumulation and genotoxic effects in marine mussels, Mytilus galloprovincialis

Holly B.C. Pearson ${ }^{a \S}$, Lorna J. Dallas ${ }^{b \S}$, Sean D.W. Comber ${ }^{a}$, Charlotte B. Braungardta ${ }^{\mathrm{a}}$, Paul J Worsfold ${ }^{\mathrm{a}}$, Awadhesh N. Jha ${ }^{\mathrm{b} *}$

aSchool of Geography, Earth \& Environmental Sciences, University of Plymouth, Drake Circus, Plymouth, PL4 8AA, UK

bSchool of Biological and Marine Sciences, University of Plymouth, Drake Circus, Plymouth, PL4 8AA, UK

$\S$ Contributed equally to the study

* Correspondance: Professor Awadhesh N. Jha

Email: a.jha@plymouth.ac.uk 


\section{Highlights:}

- Marine mussels exposed to tritiated water (HTO), zinc (Zn) and organic carbon( humic acid), alone or in combinations for 14 days

- Tritium and Zn partitioning in soft tissues in association with humic acid investigated

- DNA damage in haemocytes and tissue-specific tritium accumulation varied with time

- Interaction of humic acid variable; strong HTO-DOC association in the first 3 days

- Antagonistic effect of Zn on HTO-induced DNA damage for the concentrations used 


\begin{abstract}
Release of tritium $\left({ }^{3} \mathrm{H}\right)$ in the marine environment is of concern with respect to its potential bioaccumulation and detrimental impact on the biota. Previous studies have investigated the uptake and toxicity of this radionuclide in marine mussels, and the interaction of ${ }^{3} \mathrm{H}$ with dissolved organic ligands and elevated temperature. However, despite the well-established view that toxicity is partly governed by chemical speciation, and that toxic effects of mixture of contaminants are not always additive, there have been no studies linking the prevailing chemistry of exposure waters with observed biological effects and tissue specific accumulation of ${ }^{3} \mathrm{H}$ in combination with other constituents commonly found in natural waters. This study exposed the marine mussel Mytilus galloprovincialis for 14 days to mixtures of ${ }^{3} \mathrm{H}$ (as tritiated water, HTO) and zinc (Zn) at $5 \mathrm{Mbq} \mathrm{L}^{-1}$, and 383, 1913 and $3825 \mathrm{nM} \mathrm{Zn}$, respectively, to investigate (a) ${ }^{3} \mathrm{H}$ and $\mathrm{Zn}$ partitioning in soft tissues of mussels, and (b) DNA damage in haemocytes, determined using the single cell gel electrophoresis or the comet assay. Additionally, the extent of association of ${ }^{3} \mathrm{H}$ with dissolved organic carbon (DOC, added as humic acid) over the exposure period was investigated in order to aid the interpretation of biological uptake and effects. Results concluded a clear antagonistic effect of $\mathrm{Zn}$ on ${ }^{3} \mathrm{H}-$ induced DNA damage at all $\mathrm{Zn}$ concentrations used, likely explained by the importance of $\mathrm{Zn}$ in DNA repair enzymes. The interaction of $\mathrm{DOC}$ with ${ }^{3} \mathrm{H}$ was variable, with strong ${ }^{3} \mathrm{H}-\mathrm{DOC}$ associations observed in the first $3 \mathrm{~d}$ of the experiment. The secretion of ${ }^{3} \mathrm{H}$-binding ligands by the mussels is suggested as a possible mechanism for early biological control of ${ }^{3} \mathrm{H}$ toxicity. The results suggest risk assessments for radionuclides in the environment require consideration of potential mixture effects.
\end{abstract}

Keywords: Tritium; zinc; organic ligands; mussels; bioaccumulation; comet assay 


\section{INTRODUCTION}

The release of radionuclides into the environment is of particular concern to scientists, regulators and the general public [Dallas et al., 2012; 2016 a,b; Jha, 2008], especially in light of recent events such as the Fukishima Daiichi nuclear disaster (FDND) of 2011. Tritium $\left({ }^{3} \mathrm{H}\right)$, a radioactive isotope of hydrogen is produced and discharged in large quantities by nuclear power plants and nuclear fuel reprocessing facilities (NFRF), mostly as tritiated water. The FDND is estimated to have released between 10 and 50 thousand TBq of tritium into the NW Pacific ocean [Povinec et al., 2013]. From 2005 - 2008, the two NFRFs discharging into the English Channel//rish Sea (i.e. at Sellafield in the UK and La Hague in France) discharged ca. 1000-10000 TBq $\mathrm{y}^{-1}$ (i.e. 1-10K TBq y-1) of tritiated water (HTO) [Dallas et al., 2016 b].

Previous studies have demonstrated that ${ }^{3} \mathrm{H}$ induces DNA damage to the haemocytes of marine bivalve molluscs (e.g. oysters and mussels) at considerably below the recommended (dose) guidelines of IAEA and EURATOM. In addition ${ }^{3} \mathrm{H}$ bioaccumulates in specific tissue in these biota of ecological and economic importance [Hagger et al., 2005; Jha et al., 2005; Jaeschke et al., 2011; Devos et al., 2015; Dallas et al., 2016 a, b]. Despite this, potential modulation of these effects in a situation where organisms are co-exposed to ${ }^{3} \mathrm{H}$ and other contaminants has not been explored.

As a ubiquitous aquatic contaminant, which has recently been identified by the UK Environment Agency as a "Specific Pollutant" under the EU Water Framework Directive, zinc $(\mathrm{Zn})$ is a metal likely to be found co-localised with ${ }^{3} \mathrm{H}$. It is biologically active, playing an important role in enzyme-catalysed reactions within organisms, but potentially toxic when present in excess. In addition, $\mathrm{Zn}$ has been shown to exhibit both antagonistic and synergistic outcomes in combination with other metals. For example, a synergistic effect is observed when larvae of Mytilus galloprovincialis are exposed to $\mathrm{Zn}$ and $\mathrm{Cd}$ in combination. Markedly higher levels of metallothionein production, an indicator of metal-induced stress, has been predicted for the sum of the two metals' individual effects [Pavicic et al., 1994]. In contrast, a study on lysosomes of organisms exposed to various metals showed that $\mathrm{Zn}^{2+}$ exhibited a protective effect against damage caused by $\mathrm{Cd}^{2+}$ and $\mathrm{Cu}^{2+}[$ Viarengo et al., 2000]. Another study showed the accumulation of $\mathrm{Cd}$ in Mytilus edulis decreased, and $\mathrm{Cu}$ increased, in the presence of higher concentrations of Zn [Elliott et al., 1986]. Zinc is therefore considered a good candidate for investigating potential interactive (i.e. antagonistic, synergistic or additive) effects in combination with ${ }^{3} \mathrm{H}$.

It is known that dissolved organic ligands can ameliorate the potential toxic effects of metals in environmental waters by complexation of the biologically available free metal. Information 
on the interaction of ${ }^{3} \mathrm{H}$ with dissolved ligands is, however, limited to a few studies (e.g. Turner et al. 2009) that report chemical behaviour, without investigation of concomitant biological effects.

DNA is the important target for the action of ionising radiations (UNSCEAR, 1996). In addition, there is growing concern over the presence of those contaminants, which have the potential to induce carcinogenic, mutagenic and reproductive toxicity (Dallas et al., 2013). There has however been only limited study to evaluate potential impact of ionising radiations on the aquatic invertebrates which play important role in ecosystem functioning and which could also pose risk to human health via the food chain (Dallas et al., 2012; Jha, 2008). Furthermore, it is also appreciated that contaminants in the environment occur in all probable combinations and their bioaccumulation and toxic effects could be influenced by many confounding factors (Jha, 2008).

Within the above context, this study aimed to investigate the induction of genetic damage and tissue specific bioaccumulation of ${ }^{3} \mathrm{H}$ in marine mussel, Mytilus galloprovincialis, either alone or as binary mixtures of $\mathrm{HTO}$ and $\mathrm{Zn}$, and $\mathrm{HTO}$ and dissolved organic carbon (DOC). Following exposure of mussels to binary mixtures of differing concentrations of $\mathrm{Zn}$ and a fixed concentration of HTO, the objectives of the study were to (a) determine $\mathrm{Zn}$ speciation and the association of HTO with DOC present in the exposure waters, (b) investigate the partitioning of HTO and $\mathrm{Zn}$ inside the mussels, and (c) quantify the extent of DNA damage in haemocytes following various treatments. In order to achieve these objectives, the chemistry of the exposure water, resultant biological effects and their potential links were investigated. Anodic stripping voltammetry (ASV) and solid phase extraction (SPE) were used to investigate $\mathrm{Zn}$ speciation and HTO association with DOC in exposure waters throughout the experimental time. Post-exposure organism dissection, individual tissue analysis and evaluation of genetic damage in the haemocytes (using the single cell gel electrophoresis or the comet assay) were carried out following various treatments in the marine mussels.

\section{EXPERIMENTAL APPROACH}

\subsection{RADIATION PROTECTION}

This study was carried out within University of Plymouth's Consolidated Radioisotope Facility (CORiF, an ISO 9001 accredited laboratory) or in controlled spaces, under the guidance of the Radiation Protection Supervisor and Radiation Protection Assistant. All necessary precautions were taken to ensure minimal exposure of experimenters and colleagues to ${ }^{3} \mathrm{H}$. 


\subsection{SAMPLE APPARATUS AND REAGENTS}

Standard clean laboratory operating procedures were adhered to throughout the experiment. Ultra high purity water (UHP: resistivity > 18.2 M .cm; Elga Process Water, Bucks, UK) was used for rinsing equipment and preparing all reagents, standards and acids unless otherwise specified. Hydrochloric acid (Fisher Scientific UK, trace analysis grade) was diluted to $10 \%$ and used for all acid cleaning procedures. All glassware, a $55 \mathrm{~L}$ depuration tank (medium density polyethylene) and $25 \mathrm{~L}$ colourless plastic carboys (HDPE, Gloves4Less) were cleaned by soaking in 1\% Decon90 (Decon Laboratories Ltd, Sussex) for one week prior to acid washing (one week). Sampling bottles (LDPE, Nalgene) for metals (30,60, $500 \mathrm{~mL}$ ), DOC vials (clear glass, VWR) of volume $22 \mathrm{~mL}$, were acid soaked for one week and rinsed thoroughly before storing in sealed polyethylene bags. All glassware was ashed $\left(550^{\circ} \mathrm{C}\right.$ for 6 hours) prior to use. Zinc standards were made by dilution of stocks $\left(\mathrm{Zn}\left(\mathrm{NO}_{3}\right)_{2}(\mathrm{ROMIL}\right.$ PrimAg element reference solution) using seawater. Standards and samples (where necessary) were acidified to ca. $\mathrm{pH} 2$ using $6 \mathrm{M} \mathrm{HCl}$ (ROMIL, SpA). Humic acid (Sigma Aldrich, technical grade) standards were made up by dissolving in sodium hydroxide solution (1.7 mM, Fisher Scientific) in glass vials. For UV digestion of samples for total dissolved metal analysis, $\mathrm{H}_{2} \mathrm{O}_{2}$ (Merck, Suprapur) was used at a concentration of $15 \mathrm{mM}$. All preparation of samples for metal and DOC analyses was conducted in a class 100 laminar flow hood.

Carboys were used to collect seawater from Plymouth Sound, UK ( $S=31.5$ ) for mussel exposures. Each carboy was rinsed thoroughly three times with seawater before filling from approximately $1 \mathrm{~m}$ below the surface. Ten litres of UHP water was pumped through $0.45 \mu \mathrm{m}$ filter cartridges (Sartorius, Surrey), before seawater filtration. Full carboys were stored at $15 \pm$ $5 \stackrel{\circ}{\mathrm{C}}$ for 24 hours prior to use in the experiments.

\subsection{MUSSEL MAINTENANCE AND EXPERIMENTAL DESIGN}

Mussel collections and exposure conditions have been described in detail previously [Dallas et al. $2016 \mathrm{a}$, b]. In brief, mussels were collected from Trebarwith Strand, a pristine site located in Cornwall (latitude 50 38' 40" N, longitude 4 45' 44" W). They were packed on ice and transported to the laboratory in less than $2 \mathrm{~h}$. Mussels were depurated for 2 weeks prior to experimentation in a $75 \mathrm{~L}$ aquarium, filled with approximately $55 \mathrm{~L}$ of filtered $(<10 \mu \mathrm{m}$ ), aerated seawater at $15^{\circ} \mathrm{C}$. During this holding period, mussels were fed twice weekly with a solution of Isochrysis galbana microalgae $\left(\sim 1.05 \times 10^{6}\right.$ cells $\mathrm{mL}^{-1}$; Reed Mariculture, Campbell, CA, USA) and a $100 \%$ water change was performed $24 \mathrm{~h}$ after feeding.

Mussels were transferred to $2 \mathrm{~L}$ glass beakers $48 \mathrm{~h}$ prior to exposure at a density of 4.5 mussels $\mathrm{L}^{-1}$ (i.e. 9 mussels $^{-1}$ beaker) in order to acclimate and in line with our previous study 
(Dallas et al., 2016b). Nine mussels were exposed to one of 8 treatments (Figure 1), comprising a seawater-only control, 383,1915 or $3830 \mathrm{nM} \mathrm{Zn}$, and 4 treatments containing 5 $M B q L^{-1} \mathrm{HTO}$, which has previously shown consistent genotoxic effects in haemocytes across numerous experiments [Jha et al., 2005; Jaeschke et al., 2011; Dallas et al. 2016 a]. The 4 HTO-containing treatments also had either $0,383,1915$ or $3830 \mathrm{nM} \mathrm{Zn}$ added. These concentrations were chosen based on available LC50 data for a mussel species ( $M$. edulis) exposed to $\mathrm{Zn}$ [Ahsanullah 1976]. This experimental design resulted in a negative control (seawater only), positive control (HTO only), three different unary concentrations of $\mathrm{Zn}$, and three binary mixtures of Zn with a constant HTO concentration. Exposure was for 14 days with a feed and water change as previously described [Dallas et al. 2016 a] every $3 \mathrm{~d}$, during which the $\mathrm{Zn}$ and HTO concentrations were fully renewed.

To ensure sample species homogeneity, mussels were verified using the methods of Inoue et al. [Inoue et al. 1995], utilising polymerase chain reaction (PCR) primers to amplify specific region of a DNA strand, in this case a variable region of the Glu-5' gene (GenBank accession no. D63778). Amplification of the DNA occurs at 180 base pairs (bp) for Mytilus edulis and 126 bp for Mytilus galloprovincialis, with amplification of both bands indicative of a hybrid individual. Results from the PCR showed no M. edulis or hybrid individuals were found within the experimental animals (data not shown).

\subsection{SAMPLE CHEMISTRY}

\subsubsection{WATER QUALITY}

During both experiments, water quality parameters (dissolved oxygen, $\mathrm{pH}$, temperature) were measured daily and before / after water changes using a Hach HQ40D Multi-meter (HachLange, Dusseldorf, Germany) with associated probes and a calibrated salinometer (Orion, model 105) for salinity measurements. Water samples were taken every $3 \mathrm{~d}$ (immediately prior to water change) for measurement of tritium activity $(100 \mu \mathrm{L})$, and total dissolved $\mathrm{Zn}$ (TDZn) and ASV-labile $\mathrm{Zn}\left(\mathrm{Zn}_{\text {lab }}\right)(100 \mathrm{~mL})$ concentrations.

\subsubsection{TRITIUM ACTIVITY}

Tritium activity was measured (in triplicate) during both experiments by mixing $100 \mu \mathrm{L}$ of water with $5 \mathrm{~mL}$ of liquid scintillation cocktail (UltimaGold; Perkin Elmer Inc., Cambridge, UK) and incubation in the dark for $2 \mathrm{~h}$ prior to counting in a LS 6500 liquid scintillation counter (Beckman Coulter Inc., Brea, CA, USA) to a fixed precision of $5 \%$. 


\subsubsection{TOTAL DISSOLVED AND LABILE ZINC}

Total dissolved and ASV-labile $\mathrm{Zn}$ concentrations ([TDZn] and [ $\left.\mathrm{Zn}_{\mathrm{lab}}\right]$, respectively) were determined by anodic stripping voltammetry (ASV) using a VA computrace 797 (Metrohm) with an $\mathrm{Ag} / \mathrm{AgCl}$ reference electrode (Metrohm) and electrolyte bridge containing $3 \mathrm{M} \mathrm{KCl}$ (Metrohm) and analytical parameters given in [ $\left.Z n_{l a b}\right]$ was determined within 24 hours of collection. Prior to the determination of [TDZn], samples were acidified ( pH 2), irradiated with UV to liberate the metal from organic ligands. For both, [TDZn] and [ $\left.Z n_{\text {lab }}\right]$ determinations were made in duplicate: sample aliquots $(10 \mathrm{~mL})$ were deoxygenated with nitrogen gas, three to five repeat voltammetric scans were performed in the differential pulse mode and peak height measured using the 797 VA Computrace 1.3.2 Metrodata software. Quantification was made via two to three standard additions to each aliquot. The accuracy of the ASV method employed was verified using a certified reference estuarine water (BCR-505, European Commission) prepared for analysis as described for TDZn. The LOD was determined as $3 \times$ S.D. of the blank ( $n=3)$, using $60 \mathrm{~s}$ deposition time at maximum drop size and stirring speed.

\subsubsection{DISSOLVED ORGANIC CARBON (DOC)}

DOC was quantified using high temperature catalytic combustion (Shimadzu TOC V) following Badr et al. [Badr et al., 1995]. Samples and procedural blanks (both four replicates) were acidified (ca. $\mathrm{pH}$ 2) using $6 \mathrm{M} \mathrm{HCl}$ to purge inorganic carbon and run between acidified UHP water blanks. Average DOC concentrations from the procedural blanks were subtracted from each sample. The instrument was calibrated and a marine water certified reference material (CRM, Florida Strait 700 m depth), commercially available from University of Florida, was run each analytical day. Values were within the accepted consensus range.

\subsubsection{TRITIUM-DISSOLVED ORGANIC CARBON ASSOCIATIONS}

To assess association of ${ }^{3} \mathrm{H}$ (as HTO) with DOC, solid phase extraction was used. This method is proposed by Turner et al. [2009] as an approximate measure of the organically bound tritium (OBT) content. This includes tritium bound at exchangeable (so called exchangeable organic tritium, EOT) and non-exchangeable sites in humic substances, amino acids and aromatic ligands, and HTO occluded within dissolved organic molecules and aggregates.

Sep-Pak $\mathrm{C}^{18}$ cartridges (Waters ${ }^{\odot} 3$ cc Vac Cartridge, $500 \mathrm{mg}$ sorbent per cartridge, 55-105

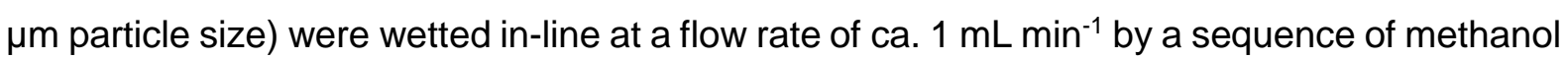
(5 mL, Fisher, HPLC grade) and UHP water $(25 \mathrm{~mL})$, twice. Cartridges were not allowed to run dry at any point. Sample was pumped through the cartridge at the same flow rate and the 
initial $4 \mathrm{~mL}$ tipped to waste, the remaining sample was collected in a scintillation vial. The cartridge was eluted with methanol $(8 \mathrm{~mL})$, which was collected into a second scintillation vial. Subsamples of the eluates were pipetted $(100 \mu \mathrm{L})$ into separate scintillation vials $(2 \mathrm{x}$ vials containing sample, $1 \times$ vial containing methanol) and mixed with scintillation cocktail $(5 \mathrm{~mL})$ before determination using a liquid scintillation counter (Beckman Coulter Inc., Brea, CA, USA). The accuracy of the method was verified by conducting scintillation counts on a known activity concentration of a stock solution of HTO. The proportion of the sample that contained tritium associated with DOC was calculated using equation 1.

$\frac{\text { Activity of eluted methanol sample }}{\text { Activity of sample }} \times 100$

\subsection{SAMPLING OF HAEMOLYMPH AND TISSUES FROM MUSSELS}

Sampling of haemolymph and tissues from mussels have been described elsewhere in detail [Jha et al., 2005; Jaeschke et al. 2011; Dallas et al., 2013; 2016a]. Briefly, after exposure, haemolymph was extracted from the posterior adductor muscle of individual mussels using a 21 gauge hypodermic needle into a $0.5 \mathrm{~mL}$ syringe pre-filled with $0.1 \mathrm{~mL}$ physiological saline (20 mM HEPES, $435 \mathrm{mM} \mathrm{NaCl}, 100 \mathrm{mM} \mathrm{MgSO}_{4}, 10 \mathrm{mM} \mathrm{KCl}, 10 \mathrm{mM} \mathrm{CaCl}_{2}, \mathrm{pH}$ 7.36) and stored on ice until use. Individual organs (i.e. digestive gland, gill, mantle, posterior adductor muscle, foot and "other", consisting of palp, gonads and siphons) were dissected from each mussel. Each dissected tissue was washed with distilled water, blotted dry and transferred to a pre-weighed and acid-washed $(10 \% \mathrm{HCl})$ vial. Determination of $\mathrm{Zn}$ and ${ }^{3} \mathrm{H}$ was carried out on dissected tissues of each individual $(n=9)$ in each treatment as specified below.

\subsubsection{ZN AND TRITIUM IN MUSSEL TISSUES}

Zn content was determined in all tissues of all individuals after tissue samples were dried to constant weight at $60^{\circ} \mathrm{C}$, re-weighed and digested in $1 \mathrm{~mL}$ concentrated $\mathrm{HNO}_{3}\left(2 \mathrm{~h}\right.$ at $\left.70^{\circ} \mathrm{C}\right)$. Digested samples were diluted to a final volume of $5 \mathrm{~mL}$ with Milli-Q water and stored at room temperature in the dark until determination (in triplicate) using a Varian 725-ES ICP-OES (Agilent Technologies Ltd, Wokingham, UK). Instrumental drift was monitored using an internal standard of $115-\ln \left(10 \mu \mathrm{g} \mathrm{L}^{-1}\right)$. Although indium has an atomic mass higher than $\mathrm{Zn}$, it was selected based on its minimal occurrence in marine samples and low polyatomic interference with seawater. The limit of detection (LOD; $3 \times$ S.D.) and limit of quantification (LOQ; $10 \times$ S.D.) were determined from 6 replicate analyses of Milli-Q water during each run of the apparatus. 
For measurement of tritium activity concentrations, larger tissues (gills and mantle) were chopped into finer pieces and freeze-dried to constant pressure, re-weighed and solubilised using $1 \mathrm{~mL}$ of Soluene-350 (Perkin Elmer Inc., Waltham, MA, USA) at $50{ }^{\circ} \mathrm{C}$ for at least $48 \mathrm{~h}$. Following solubilisation, $10 \mathrm{~mL}$ of liquid scintillation cocktail (UltimaGold, Perkin Elmer Inc., as above) was added to each vial and the resulting solution was acidified with $100 \mu \mathrm{L}$ of glacial acetic acid. Samples were then counted using liquid scintillation as above. Total activity concentrations were estimated using dry values for each tissue plus the mean activity in expelled water (measured after extraction from the freeze drier and normalised for the number of tissues in each batch/treatment). Dry activity concentrations are not reported as they exclude the large contribution to activity from free water (so called "tissue free water tritium, TFWT) [Dallas et al., 2016a]. The TFWT is tritium that is non-organically incorporated (i.e. in the water trapped within mussel tissues [Jaeschke et al., 2011]), but requires quantification for an accurate estimation of tritium dose. In this study, treatment mean values were calculated from the resulting individual dose rates, which were calculated using total activity concentrations and the ERICA tool [Brown et al., 2008]. The ERICA tool is a software programme for a tiered-based risk assessment of radioactivity in the environment. Tier 1 allows input of information concerning a specific scenario to assess risks to wildlife. Tier 2 allows input of water or biota activity concentrations to calculate dose-rate, which is compared against a dose-rate screening value (either $10 \mu \mathrm{Gy} \mathrm{h} \mathrm{h}^{-1}$ [Garnier-Laplace and Gibin 2006] or $400 \mu \mathrm{Gy} \mathrm{h}{ }^{-1}$ [UNSCEAR 1996] to qualify potential need for concern and provide guidance on further risk assessment (Tier 3).

\subsubsection{DETERMINATION OF DNA DAMAGE USING THE COMET ASSAY}

The single cell gel electrophoresis or the comet assay was carried out to determine induction of DNA damage for each individual animal as described by us in earlier publications [Jha et al., 2005; Dallas et al., 2013]. Prior to performance of the assay, total cell counts were taken and cell viability was checked using Eosin $Y$ stain and was found to be $>90 \%$ for all treatments (data not shown). For comet assay, briefly, slides were pre-coated with normal melting point agarose (NMPA; $1.5 \%$ in Milli-Q water). Haemolymph-saline suspension (200 $\mu \mathrm{L}$ ) was centrifuged at $350 \mathrm{~g}$ for $3 \mathrm{~min}$ at $4{ }^{\circ} \mathrm{C}$, resuspended in $150 \mathrm{~L}$ of LMPA $(0.75 \%$ in phosphate buffered saline, PBS) and added to NMPA-coated slides as two $75 \mathrm{~L}$ microgels. Slides were refrigerated at $4{ }^{\circ} \mathrm{C}$ for $1 \mathrm{~h}$ to allow gels to set before being exposed to $1 \mathrm{~h}\left(4^{\circ} \mathrm{C}\right)$ in lysis solution (2.5 M NaCl, $100 \mathrm{mM}$ EDTA, $10 \mathrm{mM}$ Tris, $1 \% \mathrm{~N}$-lauryl- sarcosine, $1 \%$ Triton $\mathrm{X}-100$, $10 \%$ DMSO, pH adjusted to 10 with $\mathrm{NaOH}$ ). After lysis DNA was allowed to unwind under alkaline conditions ( $1 \mathrm{mM}$ EDTA, $0.3 \mathrm{M} \mathrm{NaOH}, \mathrm{pH}$ 13) for $20 \mathrm{~min}$ at $4{ }^{\circ} \mathrm{C}$, followed by electrophoresis for $20 \mathrm{~min}\left(1 \mathrm{~V} \mathrm{~cm}^{-1}\right)$. Slides were neutralised for $10 \min$ in $0.4 \mathrm{M}$ Tris $(\mathrm{pH} 7)$, 
rinsed three times with distilled water and allowed to air dry. Each replicate microgel was stained with $20 \mu \mathrm{L}$ of $20 \mu \mathrm{g} / \mathrm{mL}$ ethidium bromide, and 50 cells per microgel (100 per slide) were scored using an epifluorescence microscope (DMR; Leica Microsystems, Milton Keynes, UK) and imaging system (Comet IV, Perceptive Imaging, Bury St Edmunds, UK). Slides were coded and randomised to ensure scoring was blind. Comet assay software packages provide a number of different parameters, \% tail DNA is considered to be the most reliable [Kumarravel and Jha, 2006] and has been successfully validated with in vitro hydrogen peroxide exposure [Dallas et al., 2013]. Therefore, comet assay results are reported as \% tail DNA.

\subsubsection{STATISTICAL ANALYSIS}

All data were assessed for normality, homogeneity of variance, skewness and kurtosis by visual inspection of residuals. Goodness of fit was determined by comparison of Akaike's Information Criterion (AIC) values [Akaike, 1973]. Appropriate parametric or non-parametric tests were used as a result of these analyses and are detailed in the appropriate results sections and figure legends.

\section{RESULTS AND DISCUSSION}

\subsection{QUALITY CONTROL}

Percent recoveries of total dissolved $\mathrm{Zn}$ in aquatic CRMs as determined by ASV were all within $92.1-100.1 \%$ (certified concentration $172.3 \pm 11 \mathrm{nM} \mathrm{Zn)}$ ). The ASV LOD was determined to be $2 \mathrm{nM} Z \mathrm{Zn}$. In mussel tissue CRM percent recovery for determining Zn by ICP-MS was lower than the tolerance range $(80.5 \%)$, for reasons that are unclear. Results were corrected (measured concentration $/ 80.5 \times 100$ ) to account for this. The precision of ICP-MS was determined as $\leq 5 \% \operatorname{RSD}(n=3)$ and the LOD was $112 \mathrm{nM} \mathrm{Zn}$. Adsorption of $\mathrm{Zn}$ to the exposure beaker walls was determined by rinsing with dilute acid solution $(10 \% \mathrm{HCl}, \mathrm{ROMIL}$ $\mathrm{SpA}$ ) and ASV analysis. The loss of $\mathrm{Zn}$ via adsorption was considered negligible with respect to the concentrations dosed during testing, at $19 \pm 3 \mathrm{nM}$. For DOC analysis, the recovery from the CRM was $115.5 \%$ and the LOD was $3.33 \mu \mathrm{M} \mathrm{C}(n=4)$.

Water quality parameters remained relatively stable during the 14 day exposure period, with mean values \pm 1 S.D. of for $\mathrm{pH}=7.7 \pm 0.2$, dissolved oxygen saturation $=90.7 \pm 6.6 \%$, salinity $=31.9 \pm 0.2$ and temperature $=15.1 \pm 0.2{ }^{\circ} \mathrm{C}$. Lower than average dissolved oxygen (DO) concentrations were measured in treatments containing HTO + $1912 \mathrm{nM} \mathrm{Zn}$ and HTO + 83 $\mu \mathrm{M}$ DOC on day 6 (31.5 and $41.1 \%$ respectively) due to the oxygen supply tube slipping out 
the beaker. Dissolved oxygen levels returned to their normal values inside the beakers as soon as tubes were replaced. These DO concentrations (approximately $3-4 \mathrm{mg} \mathrm{L}^{-1}$ ) are not deemed harmful to mussels which require a minimum of $1-2 \mathrm{mg} \mathrm{L}^{-1} \mathrm{DO}$ for normal healthy function [EPA, 2000].

\subsection{WATER CHEMISTRY}

\subsubsection{DISSOLVED ORGANIC CARBON (DOC)}

Dissolved organic carbon concentrations determined throughout the exposure period are shown in Figure 2. Although no consistent trend is apparent across different treatments, there were significant inputs of organic carbon above nominal concentrations at the beginning of the experiment in the case of the DOC-only and the HTO + 83.3 $\mu \mathrm{M} \mathrm{DOC}$ treatments. The former decreased gradually throughout the exposure period, but the latter initially dropped more sharply (days $3-6$ ). In contrast, DOC concentrations determined in the HTO + $833 \mu \mathrm{M} \mathrm{DOC}$ treatment were approximately half the spiked concentration, evenly decreasing to around a quarter by day 14 . The seawater control and the $\mathrm{HTO}+8.3 \mu \mathrm{M} \mathrm{DOC}$ treatment profiles tracked one another, with a sharp increase in DOC from day 3 to day 6 , returning to the original concentration for the remainder of the experiment.

The strict adherence to clean laboratory procedures and careful covering of beakers when not sampling meant that contamination of DOC was eliminated as a possibility. Therefore, observed DOC concentrations higher than the spike can be attributed to biological activity. The likelihood that this was due to spawning was rejected on the basis of visual inspections during the exposure. Exudation of organic material from the mussels at day 3 (or 6) of the experiment is conceivable via the production of 'transparent exopolymer particles' (TEPs). In the marine environment, microorganisms, such as phytoplankton or bacteria, exude high molecular weight mucopolysaccharides as dissolved organic matter. The latter is converted to particulate organic matter through microbial and abiotic processes, and subsequently results in TEP formation. This is a natural process by which carbon is recycled and made utilisable to pelagic and benthic feeding organisms [Heinonen et al., 2007]. Stress-related release of dissolved organic material specifically in response to HTO has not been documented, but the production of TEPs by mussels and other benthic suspension feeders has been reported [Heinonen et al., 2007]. Physiological stress has resulted in sloughing off of mucus-covered cells from organism body-linings and feeding structures [Potter et al, 1997; MacDonald et al., 1995] and the increased production of mucus [Heinonnen et al. 2007] in response to increased contaminant exposure. Mucus, a complex carbohydrate sulfate, is known to sequester both particulate and dissolved metals [Cunnigham, 1979] and would likely contribute to increased 
dissolved organic matter in the water column and TEP production [Heinonen et al., 2007]. A combined field and laboratory study of several actively pumping benthic suspension feeders [Heinonen et al., 2007] found TEP production to significantly increase in laboratory studies and increased concentrations of DOC in close proximity to dense mussel beds were determined in the field. Therefore, it is possible the mussels were responsible for the elevated concentrations of DOC measured during the present experiment.

\subsubsection{TRITIUM-ORGANIC CARBON ASSOCIATION}

Between 78 and $100 \%$ of the tritium was associated with DOC (Figure 3) during the first three days of the exposure period. This proportion was considerably higher than later in the experiment (10-15\%), for all treatment types. Tritium can substitute hydrogen in any organic compound [26] and has been reported to rapidly equilibrate with dissolved organic ligands [Turner et al., 2009]. Organic ligands may contain a variety of functional groups, which influence the strength of ${ }^{3} \mathrm{H}$ binding and organically bound tritium (OBT) is associated with strong carbon-tritium bonding [Jaeschke et al., 2011]. Exchangeable organic tritium (EOT) is relatively weakly bonded to oxygen, sulphur, nitrogen or phosphorus. The ammonia and orthophosphate mussels excrete as part of their natural digestive process [Dame and Dankers, 1988] may contribute to weak tritium bonding within the water column.

The time-significant change in organically bound tritium was independent of treatment type, which indicates that the added (humic) DOC was not responsible for the significant ${ }^{3} \mathrm{H}-\mathrm{DOC}$ association seen at day 3 (Figure 3). In all treatment types, the number of moles of DOC per Becquerel of tritium was equal to $0.03-0.19 \mathrm{nM}$. This differs by $1-2$ orders of magnitude from the results of Turner et al. [2009] (1.63 nM), who determined $\sim 6 \%$ of tritium added to natural seawater (containing $81.6 \mu \mathrm{M} \mathrm{DOC}$ ) to be associated with hydrophobic organic matter, reaching equilibrium after $24 \mathrm{~h}$. Assuming the active carbon content of the measured DOC in the exposure waters is $50 \%$ of the DOC concentration further reduces the potential for exchangeable or organically bound tritium. This value is similar to what was observed here from day 6 onwards, suggesting saturation of the dissolved ligands with ${ }^{3} \mathrm{H}$ in all test beakers. However, saturation, dependent on the HTO: ligand ratio, could not be verified as the nature of complex humic molecules remains poorly defined.

Tritium speciation in the HTO + DOC $83 \mu \mathrm{M}$ treatment on day 3 shows $100 \%$ of the ${ }^{3} \mathrm{H}$ was associated with DOC, which corresponds to the determined DOC concentration above the spike (Figure 2). This is not reflected on day 6 by the seawater control and HTO + DOC 8.3 $\mu \mathrm{M}$, providing further evidence that the extent of association of tritium with organic molecules could be a function of DOC type, rather than simply concentration. Such observations have 
been noted for metals [Pearson et al., 2017], but not previously been reported for ${ }^{3} \mathrm{H}$. Although not directly investigated during this study, a tentative explanation for the extensive association on day 3 may be provided by the incorporation of ${ }^{3} \mathrm{H}$ into organic exudates expelled into the test water by the mussels (see section 3.2.1). Whether this is evidence of a detoxifying mechanism for Mytilus galloprovincialis in contact with tritium remains unknown. There is evidence to show that behavioural responses (such as clearance rate and attachment) of this species are unaffected by exposure to HTO at these activity concentrations [Dallas et al., 2016 a]. However, the induction of mechanisms responsible for immobilising and/or excreting toxic metals, such as Cd and Zn (e.g. metallothioneins [Geret F. et al., 2002], glutathione [Canesi et al., 1998], mucus secretion [Naimo et al., 1992] and calcified concretions [Pynnonen et al., 1987]), are well documented. Additionally, physiological changes in response to increased metal exposure have been reported [Anandraj et al., 2002], so it is not unreasonable to suggest similar mechanisms exist for other contaminants, such as tritium.

Despite this interesting observation on day $3,{ }^{3} \mathrm{H}$ accumulation and partitioning in soft tissues was not investigated until the experiment's end, and the consequences of this apparently extensive binding of tritium observed at the start of the exposure period cannot be definitively related to ${ }^{3} \mathrm{H}$ accumulation (section 3.3.2) or effects of uptake (section 3.3.3).

\subsubsection{ZINC SPECIATION}

The determined ASV-labile and TDZn concentrations (Figure 4) did not reach their nominal spiked values at any time during the experiment, despite $100 \%$ water changes and renewal of contaminants every three days. However, [TDZn] was closest to nominal values at day 14 , and all spiked treatments contained $\mathrm{Zn}$ concentrations significantly above the control. Dissolved $\left[\mathrm{Zn}_{\mathrm{lab}}\right]$ and [TDZn] followed a similar trend with time (Figure 4) and the proportion of $\left[Z n_{l a b}\right]$ as percentage of [TDZn] remained relatively constant $\left(\% Z n_{l a b}=80 \pm 16 \%\right)$ throughout the exposure.

Zinc speciation data are displayed as a percentage of the [TDZn] for each treatment with time in Figure 5. In the control, \%Zn lab was similar to that in the spiked treatments on day $3(87 \%)$, but below the LOD on day 6 (Figure 5), indicating increased complexation by excessive autochthonous ligands (i.e. not the added humic DOC) at this time point (Figure 2). The \% $\mathrm{Zn}_{\text {lab }}$ in the Zn-spiked treatments ranged from $64-96 \%$ of [TDZn], whereby [ $Z \mathrm{n}_{\text {lab }}$ ] tended to increase with spiked concentrations, presumably as dissolved ligands available for complexation were progressively saturated at higher metal concentrations. There were no apparent trends over time within each treatment, showing that $\mathrm{Zn}$ speciation remained fairly consistent regardless of exposure water composition. Free $\mathrm{Zn}$ concentrations remained at a 
relatively constant proportion of [TDZn] in all treatments and the control, ranging from $4-14 \%$ $\left[\mathrm{Zn}^{2+}\right]$.

As the possibility of $\mathrm{Zn}$ loss via adsorption to beaker walls was eliminated, it could be assumed that the steady increase in dissolved Zn over the experiment (Figure 4) was concomitant with diminishing $\mathrm{Zn}$ uptake by the mussels (section 3.3.1). Although observations made elsewhere [Fraysse et al., 2002] showed stable dissolved Zn concentrations in exposure media $24 \mathrm{~h}$ following renewal, in the present study, results suggest a controlled uptake of $\mathrm{Zn}$ by the mussels, supported especially by the reduction of [TDZn] in the treatments at day 9 . The consistency in the proportions of $Z \mathrm{n}_{\mathrm{lab}}$ and $\mathrm{Zn}^{2+}$ in each $\mathrm{Zn}$-spiked treatment indicated no apparent changes in the potential bioavailability, which is incongruent with the possible exudation of complexing material by the mussels discussed in section 3.2.1. Presumably, the added $\mathrm{Zn}$ was sufficient to effect ligand saturation, even at the lowest concentration (382 nM $\mathrm{Zn})$.

\subsection{BIOLOGICAL UPTAKE AND EFFECTS OF CONTAMINANTS}

\subsubsection{ZINC UPTAKE AND PARTITIONING}

The concentration of $\mathrm{Zn}$ taken up by the mussels was calculated using equation 2 .

$\left(\left[\mathrm{Zn}_{\text {spiked }}\right]+\left[\mathrm{Zn}_{\text {background }}\right]\right)-[\mathrm{TDZn}]$

Where $\mathrm{Zn}_{\text {background }}$ was total dissolved $\mathrm{Zn}$ measured in the exposure water before spiking (64 $\mathrm{nM})$, and [TDZn] is the total dissolved concentration of Zn measured using ASV.

Figure 6 shows uptake of $\mathrm{Zn}$ by the mussels varied, with a general trend in all treatments to decrease at the end of the experiment. No significant effect was found (non-parametric Kruskal-Wallis test, $p>0.05$ ) on the measured concentration of total and labile $\mathrm{Zn}$ in the presence/absence of tritium.

Although mean tissue and whole body concentrations of $\mathrm{Zn}$ (Figure $7 \mathrm{~A}$ and $\mathrm{B}$, respectively) appeared to increase with dissolved $\mathrm{Zn}$ concentration, in keeping with previous studies [Blackmore and Wang, 2002], these were not deemed significant (factorial ANOVA, $p>0.05$ ). This is likely due to (i) the probable regulation of essential $\mathrm{Zn}$ within the exposed mussels so that tissue concentrations are not reflective of exposure concentrations [Anandraj et al. 2002] (see later in this section) and (ii) the naturally high concentrations of $Z n$ already present in the mussels (whole body $\mathrm{Zn}$ concentrations in control mussels $\approx 6.5 \mu \mathrm{M}$ ), making it difficult to detect significant changes in tissue accumulation. 
Whole soft tissue $\mathrm{Zn}$ concentrations in the different treatments (Figure $7 \mathrm{~B}$ ) ranged from $\sim 3.8$ $-7.6 \mu \mathrm{mol} \mathrm{g}{ }^{-1}$ (mean $6.1 \mu \mathrm{mol} \mathrm{g}{ }^{-1}$ ). The values are similar to those observed in another study on this species [Soto et al., 1996], but higher than $\mathrm{Zn}$ concentrations $\left(1.2 \mu \mathrm{mol} \mathrm{g}{ }^{-1}\right)$ in soft tissues of Mytilus galloprvincialis taken from an unpolluted site in northern Italy [Adami et al. 2002]. This variation in whole body metal concentrations in mussels in the environment is not unexpected [Andersen et al. 1996], and although Cantillo [1998] suggests mussels containing $\geq 3.1 \mu \mathrm{mol} \mathrm{g}{ }^{-1}$ are indicative of contamination, this is not species specific. Variations in local mineralogy, water quality (e.g. salinity and temperature) and biological factors (e.g. age, diet, body weight, reproductive state and gender) will affect accumulation and natural background tissue concentrations [Pastor et al., 1994; Lowe and Moore, 1979; Simpson, 1979].

Concentrations of $\mathrm{Zn}$ in mussel tissues ranged from $\sim 0.8-28 \mu \mathrm{mol} \mathrm{g}^{-1}$ (Figure $7 \mathrm{~A}$ ), which is in general agreement with the literature [George and Pirie, 1980; Brooks and Rusby, 1965; Segar et al., 1971; Besada et al., 2002], and varied in the order gill > digestive gland > muscle > mantle $>$ foot $=$ other. The occurrence of, in many cases, significantly higher (Tukeys post hoc, $p<0.05) \mathrm{Zn}$ concentrations in the gills can be explained by mussels being filter-feeders and their gills are the primary site for metal uptake via diffusion across the gill epithelium [Dragun et al., 2004]. Gills act as a reservoir for metals and significant accumulation in mussel gill tissue has been observed previously [Denton and Burdon-Jones, 1981]. Interestingly, the gills of the mussels in the HTO treatment contained on average less $\mathrm{Zn}$ than those in the control (although this was not statistically significant). If the exudation of mucus and organic material as a stress-response to ${ }^{3} \mathrm{H}$ exposure did occur in this treatment (DOC not measured), it could be suggested that concomitant biological secretion of $\mathrm{Zn}$-binding ligands could have reduced the uptake of $\mathrm{Zn}$.

$\mathrm{Zn}$ is an essential trace element and evidence for $\mathrm{Zn}$ regulation has been reported for a number of aquatic species [Wright, 1995], including freshwater mussels [Kraak et al., 1994; a, b] and saltwater mussels [Yap et al., 2002; Phillips 1985; Amiard et al., 1986]. Specific occurrence of this phenomenon has been suggested for Mytilus galloprovincialis but not yet been proven [Regoli and Orlando 1994]. Other studies investigating metal uptake by marine organisms have observed that $\mathrm{Zn}$ uptake does not occur as a function of water concentration, unlike non-essential elements such as cadmium [Gambardella et al., 1998; Adam et al., 2002], also leading to the conclusion that self-regulation of the essential trace elements is apparent.

\subsubsection{TRITIUM UPTAKE AND PARTITIONING}

Tritium tissue activity concentrations (Figure 8Error! Reference source not found.) in the control mussels were below the limits of quantification, but those exposed to tritiated water 
contained concentrations ranging from $\sim 4-12 \mathrm{MBq} \mathrm{kg}^{-1}$ (and were therefore all significantly different from the control). Some significant differences in tritium activity were found between individual tissues within the same treatment (factorial ANOVA, $p<0.05$ ), and in whole mussels between treatments containing/not containing added DOC (one-way ANOVA with Tukey's post hoc tests, $p>0.05)$.

Tissue specific accumulation within treatments varied in the order digestive gland $>$ foot $>$ gill $>$ mantle $>$ other $>$ muscle, with a considerable number of significant differences found between the digestive gland and foot. Tissue activity concentration differences have been observed previously [Jha et al., 2005; Jaeschke et al., 2011; Dallas et al., 2016a], although all (including this study) differ with respect to which tissues contain the highest concentrations of tritium. Jha et al. (2005) found the highest tritium accumulation in the digestive gland (as seen here), followed by the gills, concluding that uptake via the gill is followed by preferential accumulation in the gut before other organs. However, it is clear from other studies of this type that variation in tritium tissue accumulation is related to exposure concentration [Dallas et al., 2016 a], duration and the matrix.

The range of tissue activity concentrations determined here seems higher than might be expected if concentrations in mussels exposed to three times the activity concentration (but same exposure period) used in another study contained between $\sim 1-2.5 \mathrm{MBq} \mathrm{kg}^{-1}$ [Dallas et al., 2016 a]. However, comparing Dallas et al 2016a work with that of Jaeschke et al. [2011] and Jha et al., [2005], it is clear that tritium exposure concentrations and exposure periods are not proportional to tissue activity concentrations. This suggests that the biouptake and partitioning of tritium in the organs of the mussel is extremely variable and likely to be more dependent on specific mussel physiology and behaviour [Dallas et al. 2016a; Bignell et al., 2011].

Interestingly, where DOC has been added to the test medium, the average whole body tritium accumulation increases, although statistically this is not significant for all DOC-containing treatments. Nevertheless, as DOC represents a significant food source for mussels [Roditi et al., 2000], organically bound radionuclides present a more biologically available chemical form, and as equilibration of ${ }^{3} \mathrm{H}$ with DOC is rapid [Turner et al. 2009], it is possible that the bioavailability of tritium to mussels was increased with added humic matter. It is, however, not clear why this result is not more pronounced in the treatment containing the highest DOC concentrations, or why not more tritium was retained on the C-18 cartridge. If indeed exchangeable and non-exchangeable sites on organic molecules were saturated (see Figure 3), ${ }^{3} \mathrm{H}$ uptake would have been similar in all treatments. Therefore, the observed significant differences in ${ }^{3} \mathrm{H}$ accumulation with the lowest DOC spike (which represents only $6 \%$ of the 
background DOC) were more likely due to alternative factors, such as differences in individual organisms' metabolic rates and physiology.

Tritium binding and uptake during feeding was not determined during this study, but is an important point to consider. Taking account of the chemical behaviour of tritium discussed above, it is reasonable to assume much of the uptake of the contaminant by the mussels occurred in the $2 \mathrm{~h}$ following feeding (before the water change). This could have consequences for ${ }^{3} \mathrm{H}$ accumulation in other experiments where mussels were not fed, or if a different food was provided (e.g. Jha et al. 2005).

\subsubsection{DETERMINATION OF DNA DAMAGE USING THE COMET ASSAY}

DNA damage in mussel haemocytes was within expected levels [Dallas et al. 2016a] for control mussels $(4.51 \pm 1.54 \%)$, and there was a significant effect of treatments (ANOVA, $p$ $<0.001$ ) on the extent of DNA damage between the control and HTO-only, and HTO-only and Zn-spiked treatments (Fig. 90.

Most interestingly, exposure of the mussels to $5 \mathrm{MBq} \mathrm{L}^{-1}$ tritiated water alone caused a significant increase in \% tail DNA (Tukeys post hoc tests, $p<0.001$ ), but when combined with $\mathrm{Zn}$ at the concentrations used in this study, \% tail DNA was not statistically different from the control, and significantly lower than that exhibited by the HTO-only treatment. This apparent antagonistic effect of $\mathrm{Zn}$ on the genotoxicity of HTO on mussels is the first reported, and demonstrates significant protective capabilities of $\mathrm{Zn}$ when present in combination with tritium. This result is probably related to the crucial role $\mathrm{Zn}$ plays in the enzymes involved in DNA repair, so-called " $Z n$ finger proteins" $[60,61]$, which are important in regulating transcription and replication of DNA in cells [Ho, 2004].

Surprisingly, the reduction in \% tail DNA apparently caused by the presence of $\mathrm{Zn}$ is not observed alongside a decrease in the accumulation of tritium, either in individual tissues or the whole organism (Figure 8). This accumulation effect differs from observations made by Fraysse et al. (2002), who witnessed an inhibitory effect of $\mathrm{Zn}$ (at a concentration of $3824 \mathrm{nM}$ ) when freshwater mussels were co-exposed to $\mathrm{Zn}$ and the radionuclide ${ }^{57} \mathrm{Co}$. The result was attributed to decreased (whole body) accumulation, and increased depuration of accumulated

${ }^{57} \mathrm{Co}$. This was likely due to a competitive effect between $\mathrm{Zn}$ and ${ }^{57} \mathrm{Co}$ in the test medium affecting uptake via the gill, rather than internal biological processes occurring post-uptake as observed with ${ }^{3} \mathrm{H}$ exposure in this study.

Although DOC-spiked treatments appear to exhibit greater DNA damage to mussel haemocytes, reflecting the somewhat increased uptake shown in Figure 8, variability was too 
great to ascertain statistical differences between these and any of the other treatments. Similarly, \% tail DNA did appear to decrease with increasing Zn concentration, although the Zn-only treatments did not show significantly different effects from the control. As noted previously, this variability probably reflects the different physiology of individual organisms of the same species, where tolerance of some contaminant exposure is greater than others [AlSubiai et al. 2011; Jha, 2008].

\subsection{ENVIRONMENTAL IMPLICATIONS}

Mussels are a widespread and ecologically important organism, a major food source for other species including humans, and, importantly, purify waters by filtering and removing bacteria and toxins from the water column [Bayne 1976]. The implications of discharging high concentrations of radionuclides into the environment are potentially extremely damaging to the health of both aquatic and terrestrial organisms.

As tritiated water in the form of ${ }^{3} \mathrm{H}$ is discharged into the environment [Dallas et al. 2016a,b], studying the fate and behaviour of this contaminant in relation to bioavailability, partitioning, and genotoxicity to this species facilitates understanding of the mechanisms behind uptake, bioaccumulation and toxicity. By introducing another constituent, in this case $\mathrm{Zn}$, a somewhat more realistic study of the interactions between contaminants may be made to advance our knowledge of potential biological risks associated with radioactive and metallic contamination in the environment. This study also contributes important information that can be used to develop future radioactive risk assessments that are more reflective of complex environmental conditions.

\section{Conclusions}

Our study provides both chemical and biological data over an exposure duration of 14 days of marine mussels to unary and binary mixtures of zinc, tritium, and dissolved organic carbon. As, there is growing concern over the presence of those contaminants which could be carcinogenic, mutagenic and reproductive toxicants [Dallas et al, 2013], genotoxicological assessment in haemocytes of exposed mussels reveals, for the first time, evidence of antagonism when $\mathrm{Zn}$ is added at concentrations of $382-3824 \mathrm{nM}$ to exposure waters containing $5 \mathrm{MBq} \mathrm{I}^{-1}$ tritium (as HTO). A simultaneous reduction in whole-organism tritium accumulation and partitioning into tissues when mussels were exposed to mixtures of $\mathrm{Zn}$ and HTO was not observed. It could therefore be suggested that the mechanism for the reduction of toxicity in mussels is not a result of uptake concentration, but occurs later in the metabolic process. It was found that the association of ${ }^{3} \mathrm{H}$ with $\mathrm{DOC}$ in this experiment was a consistent $\sim 10-15 \%$ throughout the exposure except for the first three days, after which sampled waters 
showed that between $78-100 \%$ tritium was organically bound. This observation could be a result of mucus-secretion, similar to that reported for toxic metals. The interaction between DOC and tritium, however, requires further investigation to elucidate the effects on uptake and partitioning in tissues.

The observed protective effect of $\mathrm{Zn}$ against DNA damage induced by the widely discharged radionuclide ${ }^{3} \mathrm{H}$ could have potential protective consequences for concomitant localisation of these contaminants in the environment. These findings highlight the problems and potential for unnecessary and costly remediation of testing the toxicity of contaminants in isolation. In addition, the data presented can be used to improve the current and future risk assessment strategies for organism exposure to radionuclides in the environment. Although the concentrations used in this study were higher than expected environmental levels, identification of the antagonistic behaviour of $\mathrm{Zn}$ with tritium shows that using contaminant concentrations in isolation may lead to an incorrect prediction of risk, and so potential mixtures effects should always be considered in environmental risk assessments.

\section{Conflicts of interest}

The authors declare that they have no conflict of interest.

\section{Acknowledgments}

We thank Professor Geoff Millward (University of Plymouth, UK) for his valuable suggestions and guidance and Dr Will Vevers and Mr Nick Crocker (University of Plymouth, UK) for their technical assistance and advice. Financial Support for this study came from European Regional Development Fund, INTERREG IVA (CHRONEXPO, Grant No. 4059) and Marine Institute, University of Plymouth, UK. 


\section{REFERENCES}

Adam, C., Fraysee, B., Garnier-Lplace, J., Baudin, J.P., Boudou, A. (2002) Impact of Cadmium and Zinc Prior Exposure on 110m Silver, 58+ 60 Cobalt and 137 Cesium Uptake by Two Freshwater Bivalves During a Brief Field Experiment. Bulletin of Environmental Contamination and Toxicology 68, 428-435.

Adami, G., Barbieri, P., Fabiani, M., Piselli, S., Predonzani, S., Reisenhofer, E.(2002) Levels of cadmium and zinc in hepatopancreas of reared Mytilus galloprovincialis from the Gulf of Trieste (Italy). Chemosphere 48, 671-677.

Ahsanullah, M.(1976) Acute toxicity of cadmium and zinc to seven invertebrate species from Western Port, Victoria. Australian Journal of Marine and Freshwater Research 27, 187-196.

Al-Subiai, S.N., Moody, A.J., Mustafa, S.A., Jha, A.N. (2011) A multiple biomarker approcah to investigate the effects of copper on the marine bivalve mollusc, Mytilus edulis. Ecotoxicology and Environmental Safety 74, 1913-1920.

Akaike, H. (1973) Information theory and an extension of the maximum likelihood principle, in Proceedings of the Second International Symposium on Information Theory, B.N. Petrov and S. Caski, Editors. 1973, Akademiai Kaido: Budapest, Hungary. p. 267-281.

Amiard, J.C., Amiard-Triquest, C., Berthet, B., Metayer, C. (1986) Contribution to the ecotoxicological study of cadmium, lead, copper and zinc in the mussel Mytilus edulis. Marine Biology 90, 425-431.

Anandraj, A., Marshall, D.J., Gregroy, M.A., McClurg, T.P. (2002) Metal accumulation, filtration and $\mathrm{O} 2$ uptake rates in the mussel Perna perna (Mollusca: Bivalvia) exposed to $\mathrm{Hg} 2+$, Cu2+ and Zn2+. Comparative Biochemistry and Physiology Part C: Toxicology \& Pharmacology 132, 355-363.

Andersen, V., Maage, A., Johannessen, P.J. (1996) Heavy metals in blue mussels (Mytilus edulis) in the Bergen Harbor area, western Norway. Bulletin of Environmental Contamination and Toxicology 57, 589-596.

Asmuss, M., Mullenders, L.H.F., Eker, A., Hartwig, A. (2000) Differential effects of toxic metal compounds on the activities of Fpg and XPA, two zinc finger proteins involved in DNA repair. Carcinogenesis 21, 2097-2104.

Badr, E.-S.A., Achterberg, E.P., Tappin, A.D., Hill, S.J., Braungardt, C.B. (2003) Determination of dissolved organic nitrogen in natural waters using high-temperature catalytic oxidation. TrAC,Trends in Analytical Chemistry 22, 819-827.

Bayne, B.L., Marine Mussels: their ecology and physiology. Vol. 10. 1976: Cambridge University Press, Cambridge.

Bignell, J.P., Stentiford, G.D., Taylor, N.G.H., Lyons, B.P.(2011) Histopathology of mussels (Mytilus sp.) from the Tamar estuary, UK. Marine Environmental Research 72(1-2), 25-32.

Blackmore, G., Wang, W.X. (2002) Uptake and efflux of Cd and Zn by the green mussel Perna viridis after metal preexposure. Environmental Science \& Technology 36, 989-995.

Besada, V., Fumega, J., Vaamonde, A. (2002) Temporal trends of Cd, Cu, Hg, Pb and $\mathrm{Zn}$ in mussel (Mytilus galloprovincialis) from the Spanish North-Atlantic coast 1991-1999. Science of The Total Environment 288, 239-253.

Brown, J.E., Alfonso, B., Avila, R., Beresford, N.A., Coppstone, D., Prhl, G., Ulanovsky, A. (2008)The ERICA Tool. Journal of Environmental Radioactivity 99, 1371-1383.

Brooks, R.R., Rumsby M.G. (1965) Trace element uptake in some New Zealand bivalves. Limnology and Oceanography 10, 521-527.

Canesi, L., Ciacci, C., Piccoli, G., Stocchi, V., Viarengo, A., Gallo, G. (1998) In vitro and in vivo effects of heavy metals on mussel digestive gland hexokinase activity: the role of glutathione. Comparative Biochemistry and Physiology Part C: Pharmacology, Toxicology and Endocrinology 120, 261-268.

Cantillo, A.Y. (1998) Comparison of results of Mussel Watch Programs of the United States and France with Worldwide Mussel Watch Studies. Marine Pollution Bulletin 36, 712717. 
Cunnigham, P. (1979) The use of bivalve molluscs in heavy metal pollution research, in Marine Pollution. Functional Responses. J. Vernberg, Editor. Academic Press: New York. San Francisco. London. p. 183-222.

Dallas, L.J., Keith-Roach, M., Lyons, B.P., Jha, A.N. (2012) Assessing the impact of ionising radiation on aquatic invertebrates: a critical review. Radiation Research 177, 693716.

Dallas, L.J., Bean, T.P., Turner, A., Lyons, B.P., Jha, A.N. (2013) Oxidative DNA damage may not mediate $\mathrm{Ni}$-induced genotoxicity in marine mussels: Assessment of genotoxic biomarkers and transcriptional responses of key stress genes. Mutation Research/Genetic Toxicology and Environmental Mutagenesis 754, 22-31.

Dallas, L.J., Devos, A., Fievet, B., Turner, A., Lyons, B.P., Jha, A.N (2016a) Radiation dose estimation for marine mussels following exposure to tritium: best practice for use of the ERICA tool in ecotoxicological studies. Journal of Environmental Radioactivity 155-156, 1-6.

Dallas, L.J., Bean, T.P., Turner, A., Lyons, B.P., Jha A.N. (2016b) Exposure to tritiated water at an elevated temperature: genotoxic and transcriptomic effects in marine mussels (M. galloprovincialis). Journal of Environmental Radioactivity 164, 325-336.

Dame, R.F., Dankers, N. (1988) Uptake and release of materials by a Wadden sea mussel bed. Journal of Experimental Marine Biology and Ecology 118, 207-216.

Denton, G.R.W., Burdon-Jones, C. (1981) Influence of temperature and salinity on the uptake, distribution and depuration of mercury, cadmium and lead by the black-lip oyster Saccostrea echinata. Marine Biology 64, 317-326.

Devos, A., Dallas, L.J., Voiseux, C. Lecomte-Pradines, C., Jha, A.N., Fivet, B. (2015) Assessment of growth, genotoxic responses and expression of stress related genes in the Pacific oyster Crassostrea gigas following chronic exposure to ionizing radiation. Marine Pollution Bulletin 95, 688-698.

Dragun, Z., Erk, M., Raspor, B., Ivankovic, D., Pavicic, J. (2004) Metal and metallothionein level in the heat-treated cytosol of gills of transplanted mussels Mytilus galloprovincialis Lmk. Environment International 30, 1019-1025.

Elliott, N.G., Swain, R., Ritz, D.A. (1986) Metal interaction during accumulation by the mussel Mytilus edulis planulatus. Marine Biology 93, 395-399.

EPA (2000) Ambient Aquatic Life Water Quality Criteria for Dissolved Oxygen (Saltwater): Cape Cod to Cape Hatteras. Office of Water: Office of Science and Technology: Washington DC. p. 140.

Fraysse, B., Baudin, J.-P., Garnier-Laplace, J., Adam, C., Boudou, A. (2002) Effects of Cd and $\mathrm{Zn}$ waterborne exposure on the uptake and depuration of $57 \mathrm{Co}, 110 \mathrm{mAg}$ and $134 \mathrm{Cs}$ by the Asiatic clam (Corbicula fluminea) and the zebra mussel (Dreissena polymorpha)-whole organism study. Environmental Pollution 118, 297-306.

Gambardella, C.D.B., Cafiero, A., Guarino, G., de Nicola, S.M. (1998) Modalità ed effetti dell'accumulo subcellulare di cadmio e/o zinco in Idotea baltica (crustacea, isopoda). Acqua Aria 1, 11-16.

Garnier-Laplace, J., Gilbin, R. (2006) Derivation of Predicted-No-Effect-Dose-Rate values for ecosystems (and their sub-organisational levels) exposed to radioactive substances. Report D5 to the ERICA project (EC Contract number F16RCT-2003-508847), S.R.P. Authority, Editor. 2006: Stockholm, Sweden.

George, S.G., Pirie, B.J.S. (1980) Metabolism of zinc in the mussel Mytilus edulis (L.): A combined ultrastructural and biochemical study. Jounral of the Marine Biological Association, UK 60, 575-590.

Géret, F., Jouan, A.., Turpin, V., Bebianno, M.J., Cosson, R.P. (2002) Influence of metal exposure on metallothionein synthesis and lipid peroxidation in two bivalve mollusks: the oyster (Crassostrea gigas) and the mussel (Mytilus edulis). Aquatic Living Resources 15, 61-66.

Giaginis, C., Gatzidou, E., Theocharis, S. (2006) DNA repair systems as targets of cadmium toxicity. Toxicology and Applied Pharmacology 213, 282-290. 
Hagger, J.A., Atienzar, F.A., Jha, A.N. (2005) Genotoxic, cytotoxic, developmental and survival effects of tritiated water in the early life stages of the marine mollusc, Mytilus edulis. Aquatic Toxicology 74, 205-217.

Heinonen, K.B., Ward, J.E., Holohan, B.A. (2007) Production of transparent exopolymer particles (TEP) by benthic suspension feeders in coastal systems. Journal of Experimental Marine Biology and Ecology 341, 184-195.

Ho, E. (2004) Zinc deficiency, DNA damage and cancer risk. The Journal of Nutritional Biochemistry, 15, 572-578.

Inoue, K., Waite, J.H., Matsuoka, M., Odo, S., Harayama, S. (1995) Interspecific variations in adhesive protein sequences of Mytilus edulis, M. galloprovincialis, and M. trossulus. The Biological Bulletin 189, 370-375.

Jaeschke, B.C., Mikllward, G.E., Moody, A.J., Jha, A.N. (2011) Tissue-specific incorporation and genotoxicity of different forms of tritium in the marine mussel, Mytilus edulis. Environmental Pollution159, 274-280.

Jha, A.N.(2008) Ecotoxicological applications and significance of the comet assay. Mutagenesis 23, 207-221.

Jha, A.N., Dogra, Y., Turner, A., Millward, G.E. (2005) Impact of low doses of tritium on the marine mussel, Mytilus edulis: Genotoxic effects and tissue-specific bioconcentration. Mutation Research/Genetic Toxicology and Environmental Mutagenesis 586, 47-57.

Kraak, M.H.S., Wink, Y.A., Stuijifzand, S.C., et al. (1994) Chronic ecotoxicity of Zn and Pb to the zebra mussel Dreissena polymorpha. Aquatic Toxicology 30, 77-89.

Kraak, M.H.S., Toussaint, M.T., Lavy, D., Davids, C. (1994) Short-term effects of metals on the filtration rate of the zebra mussel Dreissena polymorpha. Environmental Pollution, 84, 139-143.

Kumaravel, T.S., Jha, A.N. (2006) Reliable Comet assay measurements for detecting DNA damage induced by ionising radiation and chemicals. Mutation Research/Genetic Toxicology and Environmental Mutagenesis 605, 7-16.

Lowe, D.M., Moore, M.N. (1976) The cytochemical distributions of zinc (Zn II) and iron (Fe III) in the common mussel, Mytilus edulis, and their relationship with lysosomes. Journal of the Marine Biological Association of the United Kingdom 59, 851-858.

MacDonald, B.A., Ward, J.E., McKenzie, C.H. (1995) Exfoliation of epithelial cells from the palliai organs of the sea scallop, Placopecten magellanicus. Journal of Experimental Marine Biology and Ecology 191,151-165.

Maycock, D., Graham, Peters, A. (2012) Proposed EQS for Water Framework Directive Annex VIII substances: copper (saltwater) (For consultation). Edinburgh.

Naimo, T.J., Atchison, G.J., Holland, L.E.(1992) Bartels, Sublethal effects of cadmium on physiological responses in the pocketbook mussel, Lampsilis ventricosa. Environmental Toxicology and Chemistry 11, 1013-1021.

Pastor, A., Hernandez, F., Persis, M.A., Beltran, J., Sancho, J.V., Castillo, M.T. (1994) Levels of heavy metals in some marine organisms from the western Mediterranean area (Spain). Marine Pollution Bulletin 28, 50-53.

Pavičić, J., Skreblin, M., Kregar, I., Tusek-Znidaric, M., Stegnart, P. (1994) Embryo-larval tolerance of Mytilus galloprovincialis, exposed to the elevated sea water metal concentrations- - . Toxic effects of $\mathrm{Cd}, \mathrm{Zn}$ and $\mathrm{Hg}$ in relation to the metallothionein level. Comparative Biochemistry and Physiology Part C: Pharmacology, Toxicology and Endocrinology 107, 249-257.

Pearson, H., Comber, S., Braungardt, C., Worsfold, P. (2017) Predicting copper speciation in estuarine waters - is dissolved organic carbon a good proxy for the presence of organic ligands? Environmental Science and Technology 51, 2206-2216.

Phillips, D.J.H.(1985) Organochlorines and trace metals in green-lipped mussels Perna viridis from Hong Kong waters:a test of indicator ability. Marine Ecology - Progress Series 21, 251-258.

Potter, T.M., MacDonald, B.A., Ward, J.E. (1997) Exfoliation of epithelial cells by the scallop Placopecten magellanicus: seasonal variation and the effects of elevated water temperatures. Marine Biology 127, 463-472. 
Povinec, P.P., Aoyama, M., Biddulph, D., Breier, R. et al. (2013), Cesium, iodine and tritium in NW Pacific waters-a comparison of the Fukushima impact with global fallout. Biogeosciences 10, 5481-5496.

Pynnönen, K., Holwerda, D.A., Zandee, D.I. (1987) Occurrence of calcium concretions in various tissues of freshwater mussels, and their capacity for cadmium sequestration. Aquatic Toxicology 10, 101-114.

Regoli, F., Orlando, E. (1994) Accumulation and subcellular distribution of metals (Cu, Fe, Mn, $\mathrm{Pb}$ and $\mathrm{Zn}$ ) in the Mediterranean mussel Mytilus galloprovincialis during a field transplant experiment. Marine Pollution Bulletin 28, 592-600.

Roditi, H.A., Fisher, N.S., Sanudo-Wilhelmy, S.A. (2000) Uptake of dissolved organic carbon and trace elements by zebra mussels. Nature 407, 78-80.

Segar, D.A., Collins, J.D., Riley, J.P. (1971) The distribution of the major and some minor elements in marine animals Part II. Molluscs. Journal of the Marine Biological Association of the United Kingdom 51, 131-136.

Simpson, R.D. (1979) Uptake and loss of zinc and lead by mussels (Mytilus edulis) and relationships with body weight and reproductive cycle. Marine Pollution Bulletin 10, 7478.

Soto, M., Cajaraville, M.P., Marigómez, I. (1996) Tissue and cell distribution of copper, zinc and cadmium in the mussel, Mytilus galloprovincialis, determined by autometallography. Tissue and Cell 28, 557-568.

Turner, A., Millward, G.E., Stemp, M. (2009) Distribution of tritium in estuarine waters: the role of organic matter. Journal of Environmental Radioactivity 100, 890-895.

UNSCEAR, Effects of radiation on the environment. United Nations Scientific Committee on the Effects of Atomic Radiation UNSCEAR 1996 Report to the General Assembley with Scientific Annex, U. Nations, Editor. 1996: New York, NY, USA.

Viarengo, A., Marro, A., Marchi, B., Burlando, B. (2000) Single and combined effects of heavy metals and hormones on lysosomes of haemolymph cells from the mussel Mytilus galloprovincialis. Marine Biology 137, 907-912.

Wright, D.A., (1995) Trace metal and major ion interactions in aquatic animals. Marine Pollution Bulletin 31, 8-18.

Yap, C.K., Ismail, A., Tan, S.G., Omar, H. (2002) Correlations between speciation of Cd, Cu, $\mathrm{Pb}$ and $\mathrm{Zn}$ in sediment and their concentrations in total soft tissue of green-lipped mussel Perna viridis from the west coast of Peninsular Malaysia. Environment International 28, 117-126. 


\section{Table Caption and Figure legends}

Table 1. Generic parameters for the determination of dissolved $\mathrm{Zn}$ using anodic stripping voltammetry.

Figure 1. Experimental design for the exposure treatments. DOC: Dissolved organic carbon, HTO: Tritiated water, SW: Seawater, Zn: Zinc. HTO was at a fixed concentration of $5 \mathrm{MBq} \mathrm{I}^{-1}$.

Figure 2. Concentrations (as $\mu \mathrm{M}$ carbon) of dissolved organic carbon (DOC) throughout the exposure period. Dashed lines represent the spiked concentrations of DOC as $\mu \mathrm{M} \mathrm{C}$ (assuming $50 \%$ is actively complexing [25]) plus background carbon $(135 \mu \mathrm{M})$ present in the seawater. Error bars are shown where larger than the marker and represent \pm 1 S.D. about the mean $(n=4)$.

Figure 3. The percentage of tritium (as tritiated water, HTO) associated with dissolved organic carbon (DOC) in each treatment for each sampling day throughout the exposure. The seawater control data is absent as the activity concentration was negligible in both the sample and eluted methanol.

Figure 4. ASV-Labile and total dissolved $\mathrm{Zn}$ concentrations measured in spiked treatments containing (A) Zn only (B) Zn and tritiated water (at $5 \mathrm{MBq} \mathrm{L}^{-1}$ ). Black dotted lines represent spiked concentrations. For clarity, the sea water control is not shown, but contains $\mathrm{Zn}$ concentrations significantly lower than those in all the $\mathrm{Zn}$ treatments ( $\leq 130 \mathrm{nM}$ TDZn throughout the exposure period). Error bars are shown where larger than the marker and represent \pm 1 S.D. $(n=3)$ about the mean.

Figure 5. Labile, complexed and free $\mathrm{Zn}$ as percentage of total dissolved $\mathrm{Zn}$ determined throughout the $14 \mathrm{~d}$ exposure in the different treatments. Note that the labile Zn concentration in the control on days 6 and 14 were < LOD, and thus $100 \%$ complexation of $\mathrm{Zn}$ was assumed.

Figure 6. Zn uptake by mussels in the spiked treatments throughout the exposure.

Figure 7. Zn concentrations in A) individual tissues and B) in whole mussels after 14 day exposure to unary and binary mixtures of $Z n$ and HTO. Error bars represent \pm standard error $(n=9)$. Significant differences (factorial ANOVA, $p>0.05$ ) between tissues within treatments are marked by letters (Ma: different from mantle, g: different from gill, d: different from digestive gland, o: different from 
other). Significant differences between whole mussel $\mathrm{Zn}$ concentrations in different treatments are marked (HTO: different from HTO treatment).

Figure 8. (A) Total activity concentrations from tritium in individual tissues and (B) whole mussels after $14 \mathrm{~d}$ exposure to single compound and binary mixtures of HTO and Zn, and HTO and DOC. Error bars represent \pm one standard error. Significant differences were calculated using a factorial ANOVA with Tukeys post hoc tests, and are indicated by asterisks for between treatment effects, and letters for within-treatment effects, i.e. differences between tissues (d: different from digestive gland, f: different from foot, $g$ : different from gill, $p<$ 0.05).

Figure 9. DNA damage (\% tail DNA) measured using the comet assay for mussel haemocytes after 14 day exposure to unary and binary mixtures of $\mathrm{Zn}$ and HTO. Data are presented as standard Tukey box plots, i.e. whiskers are $1.5 \times$ IQR and outliers are indicated as points. Significant differences between treatments of interest (coloured boxplots) are marked by asterisks (ANOVA with Tukeys post hoc tests; $\left.{ }^{* * *}, \mathrm{p}<0.001,{ }^{*} \mathrm{p}<0.05\right)$. 
Table 2 Generic parameters for the determination of dissolved $\mathrm{Zn}$ using anodic stripping voltammetry.

\begin{tabular}{ll}
\hline Parameter (unit) & Value \\
\hline Initial potential (V) & -1.2 \\
Final potential (V) & -0.9 \\
Deposition potential (V) & -1.2 \\
Step potential (V) & 0.00244 \\
Amplitude (V) & 0.025 \\
Deposition time (s) & $3-60$ \\
Equilibration time (s) & 5 \\
Stirring speed / drop size & Varied according to sample \\
\hline
\end{tabular}


Pearson- Dallas et al. Figure 1

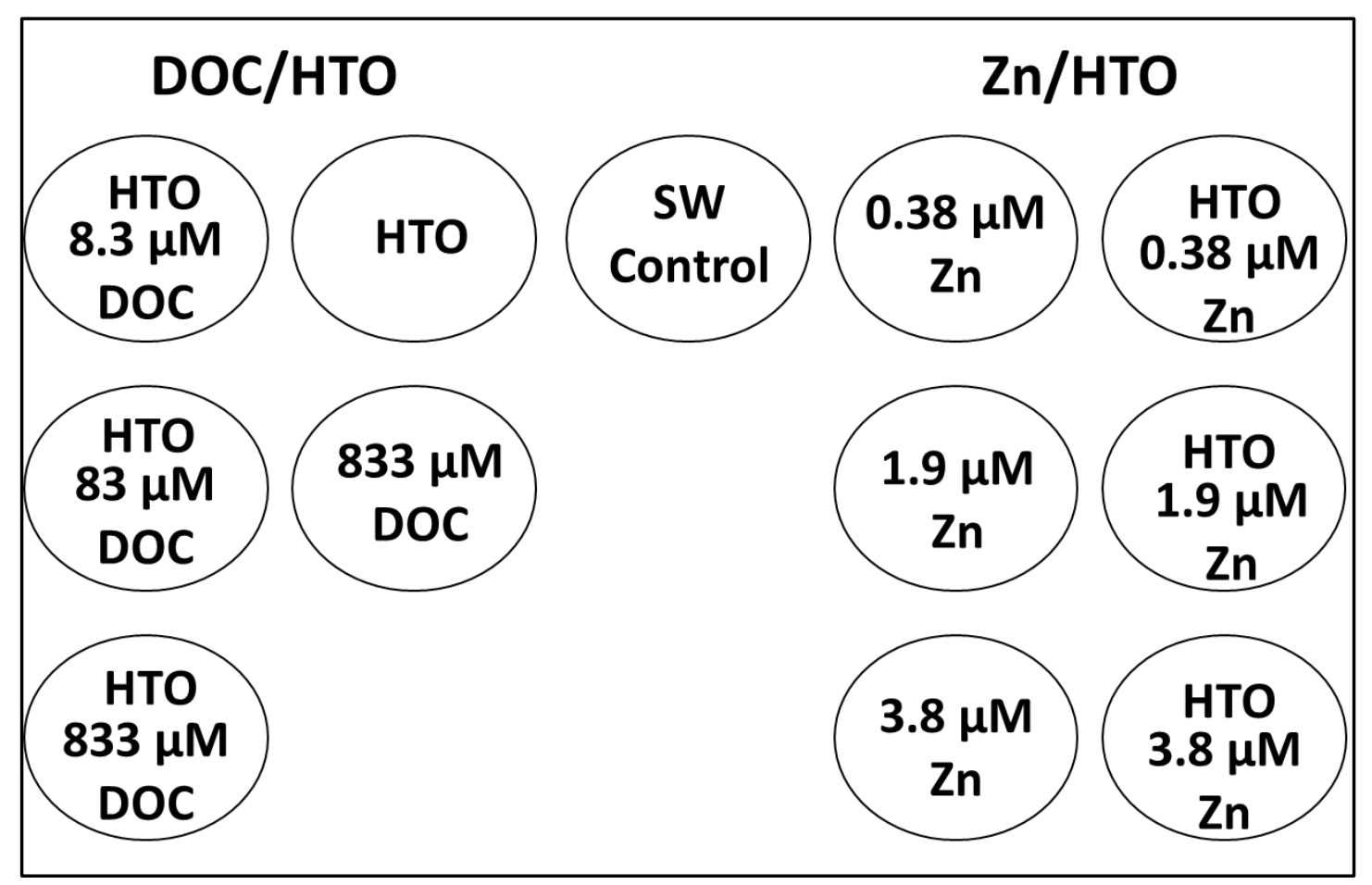


Pearson-Dallas et al. Figure 2

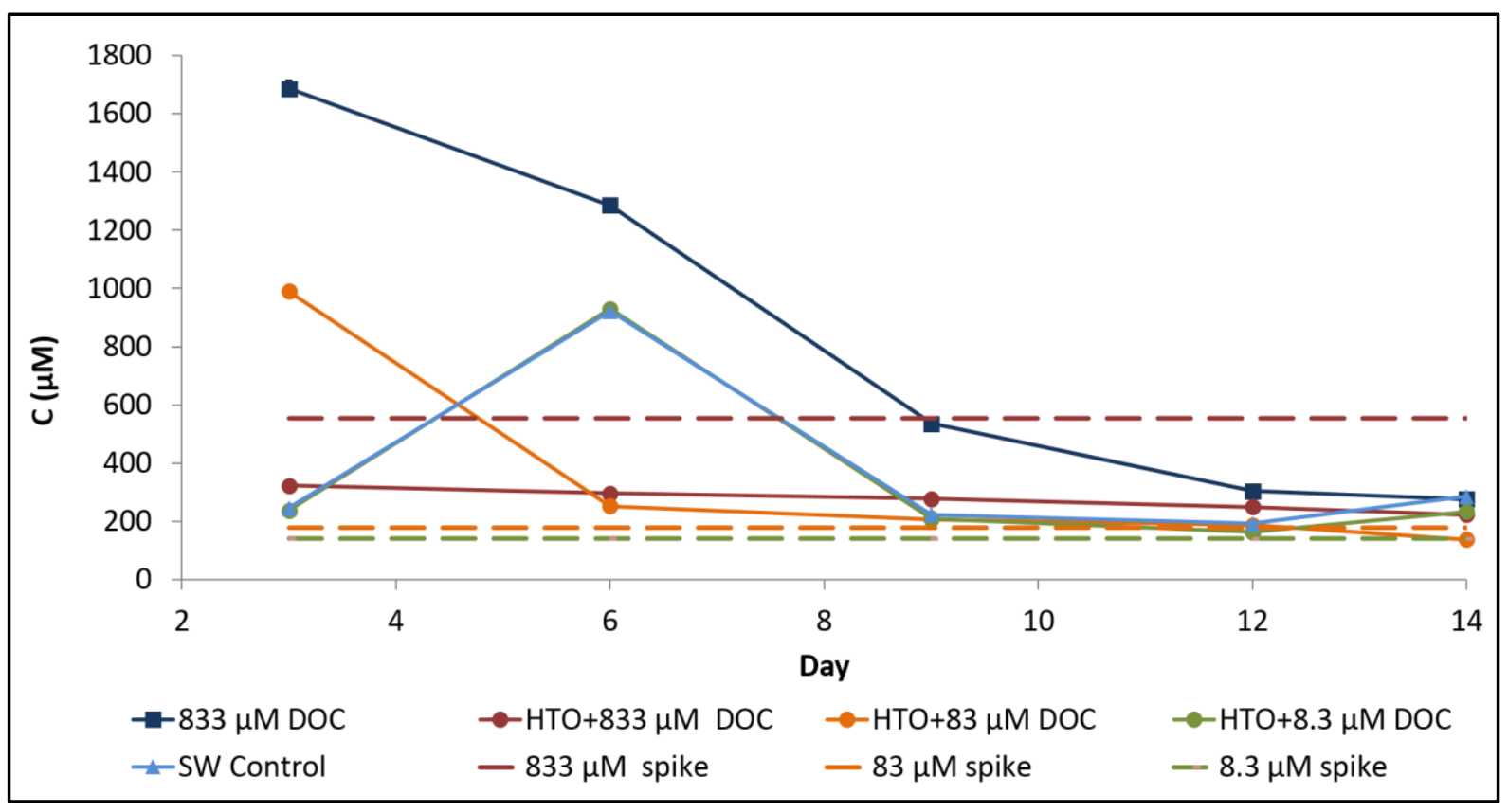


Pearson-Dallas et al. Figure 3

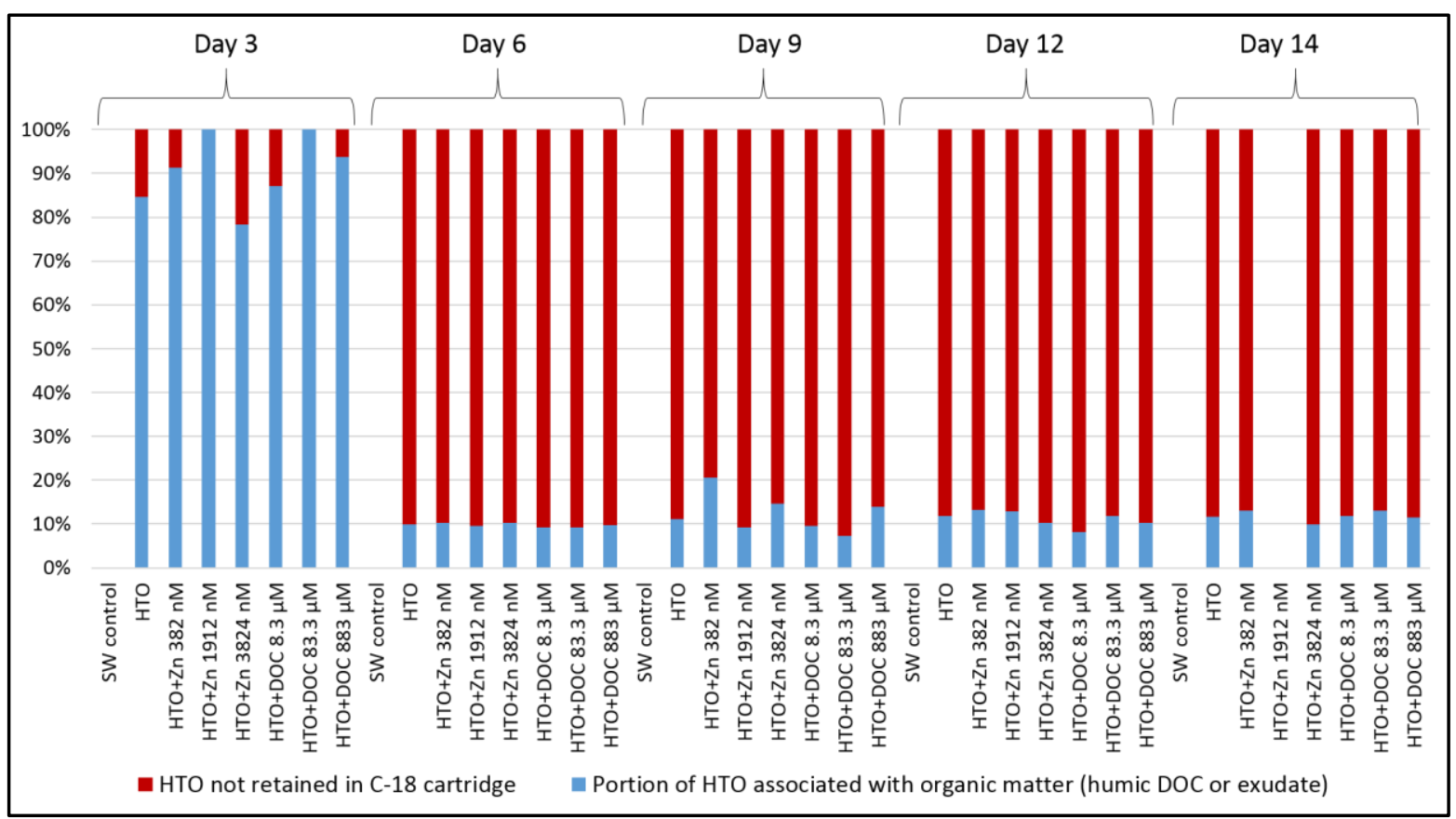


Pearson-Dallas et al. Figure 4

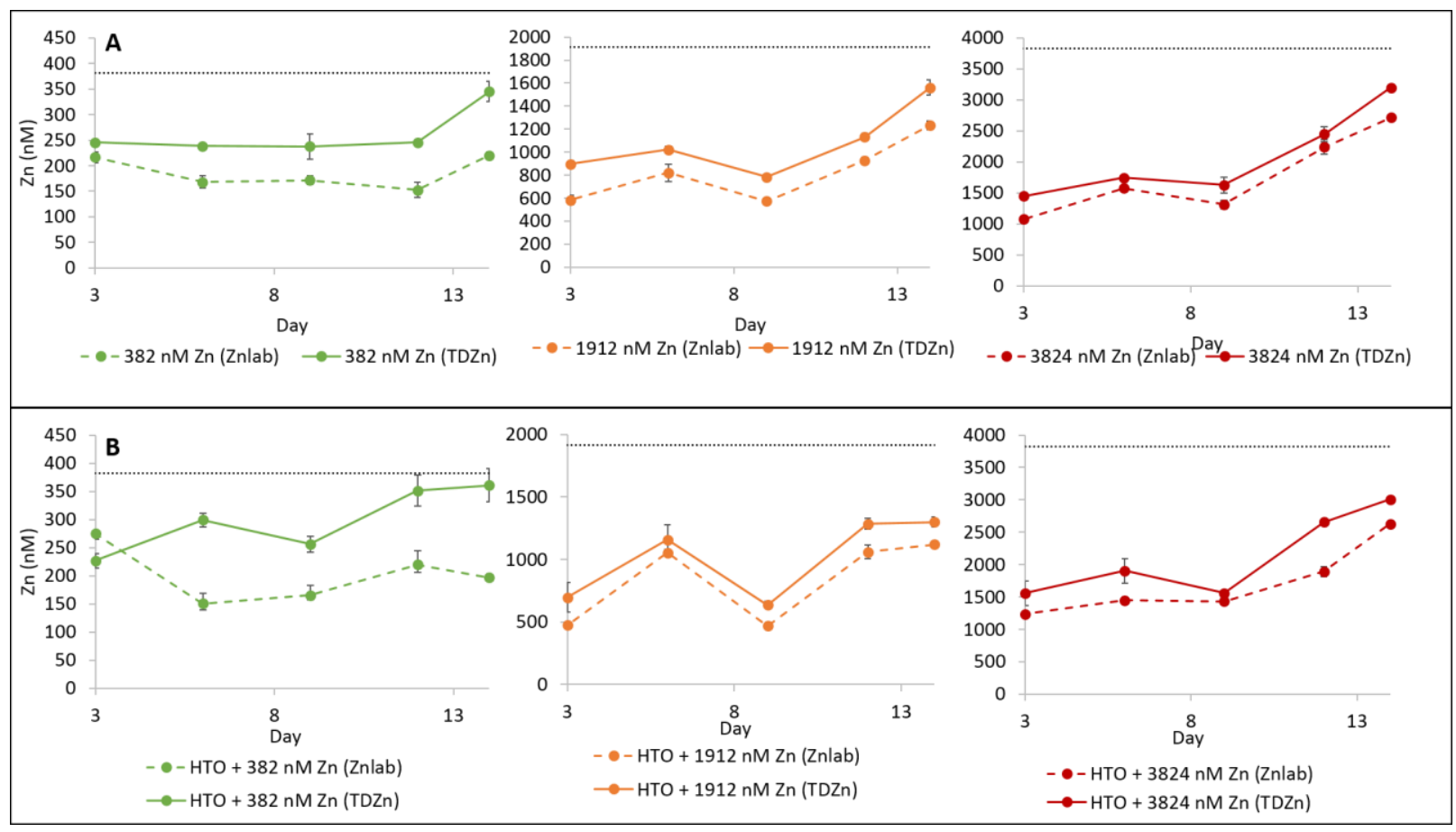


Pearson-Dallas et al. Figure 5

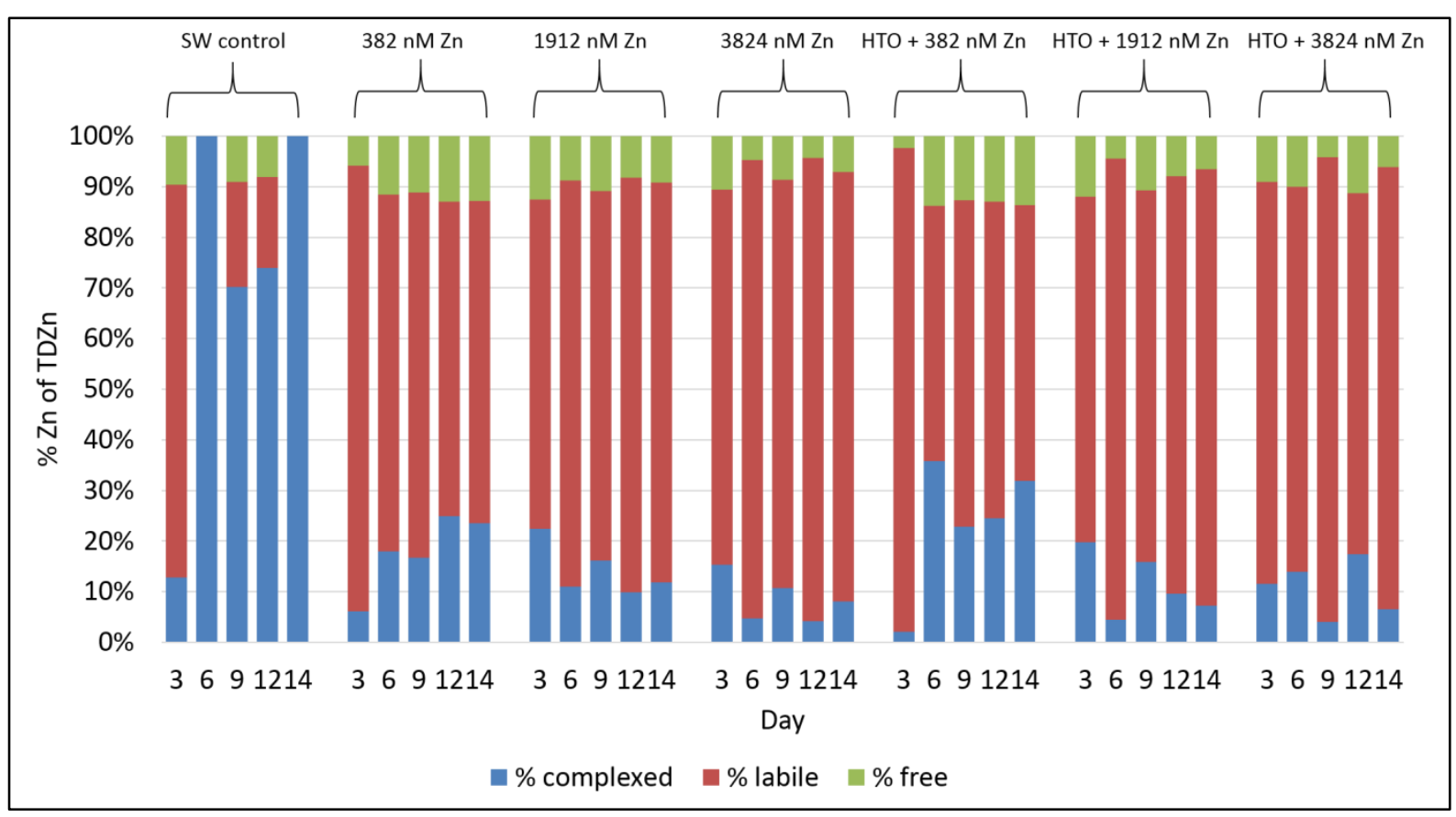


Pearson-Dallas et al. Figure 6

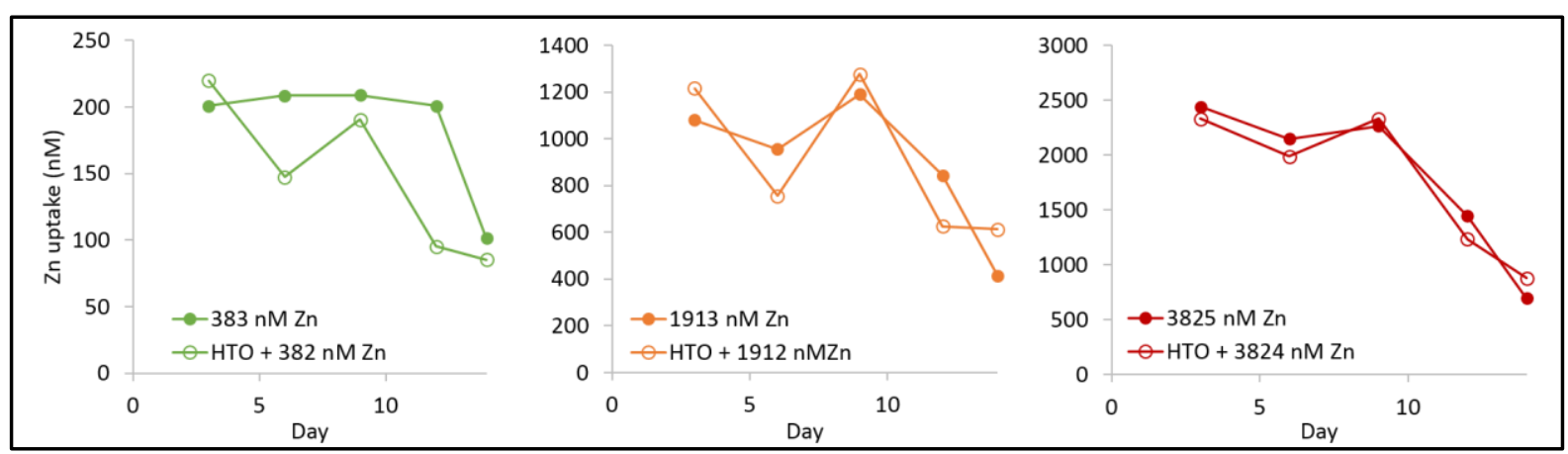


Pearson- Dallas et al. Figure 7

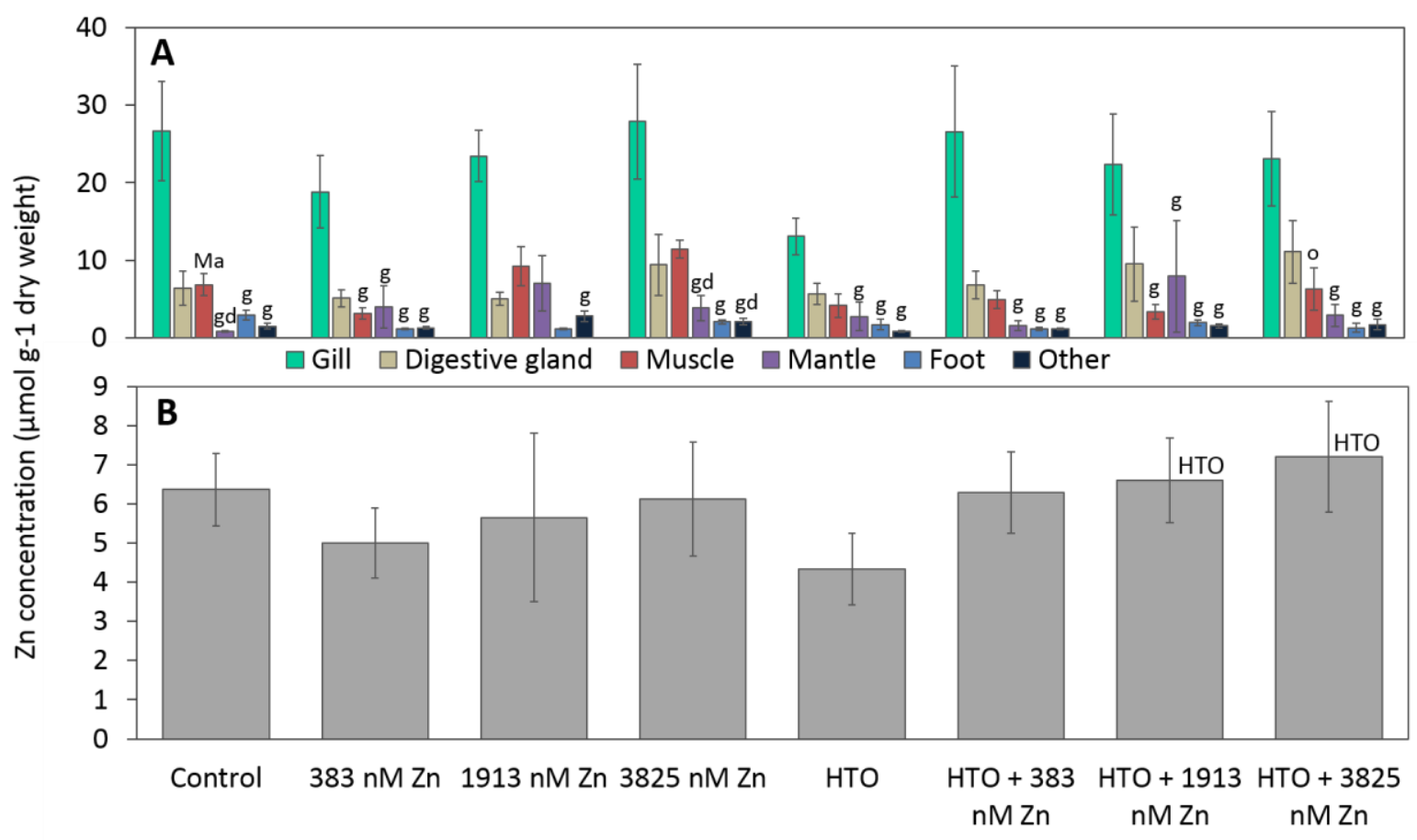


Pearson-Dallas et al. Figure 8

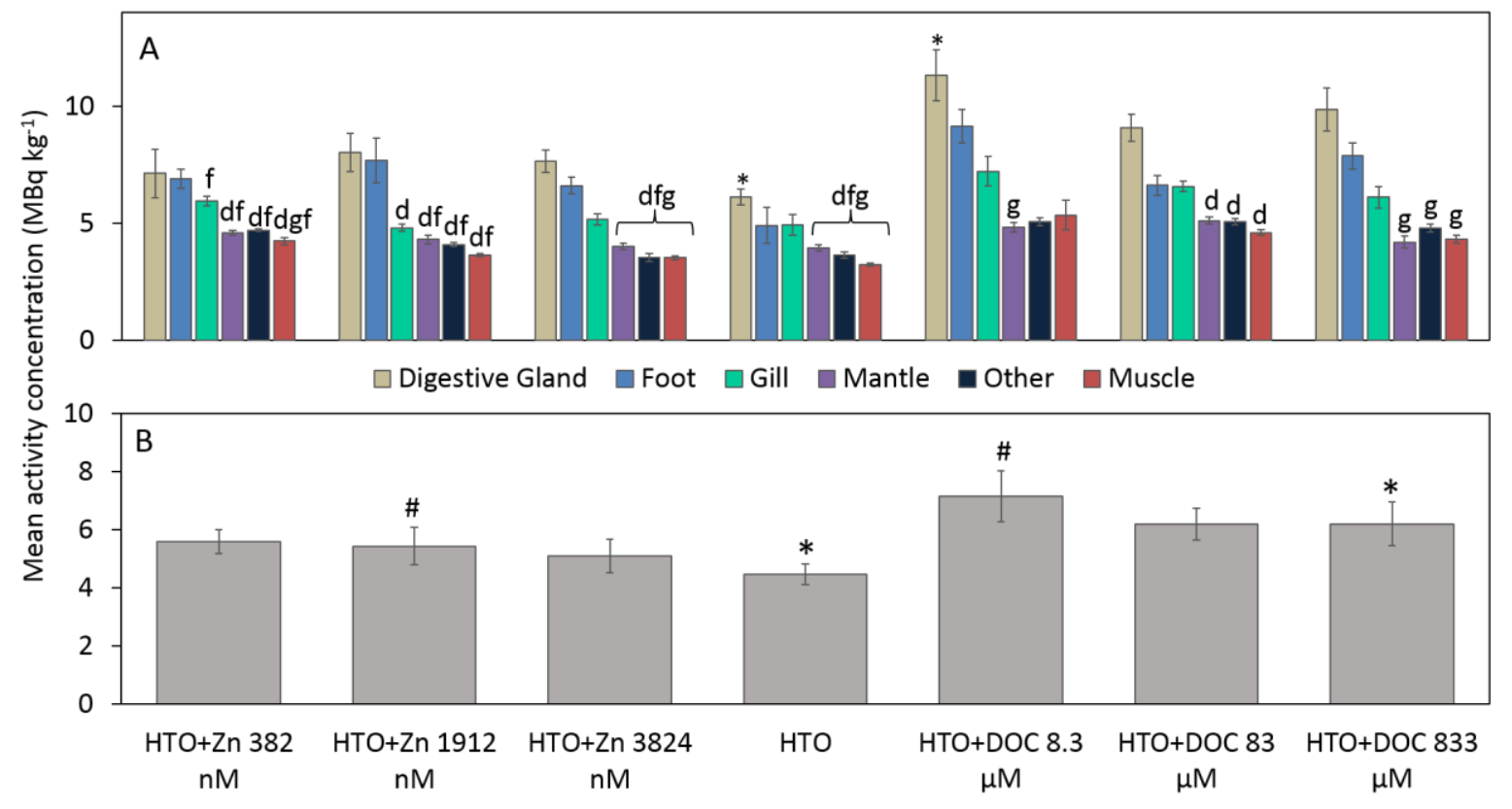


Pearson-Dallas et al. Figure 9

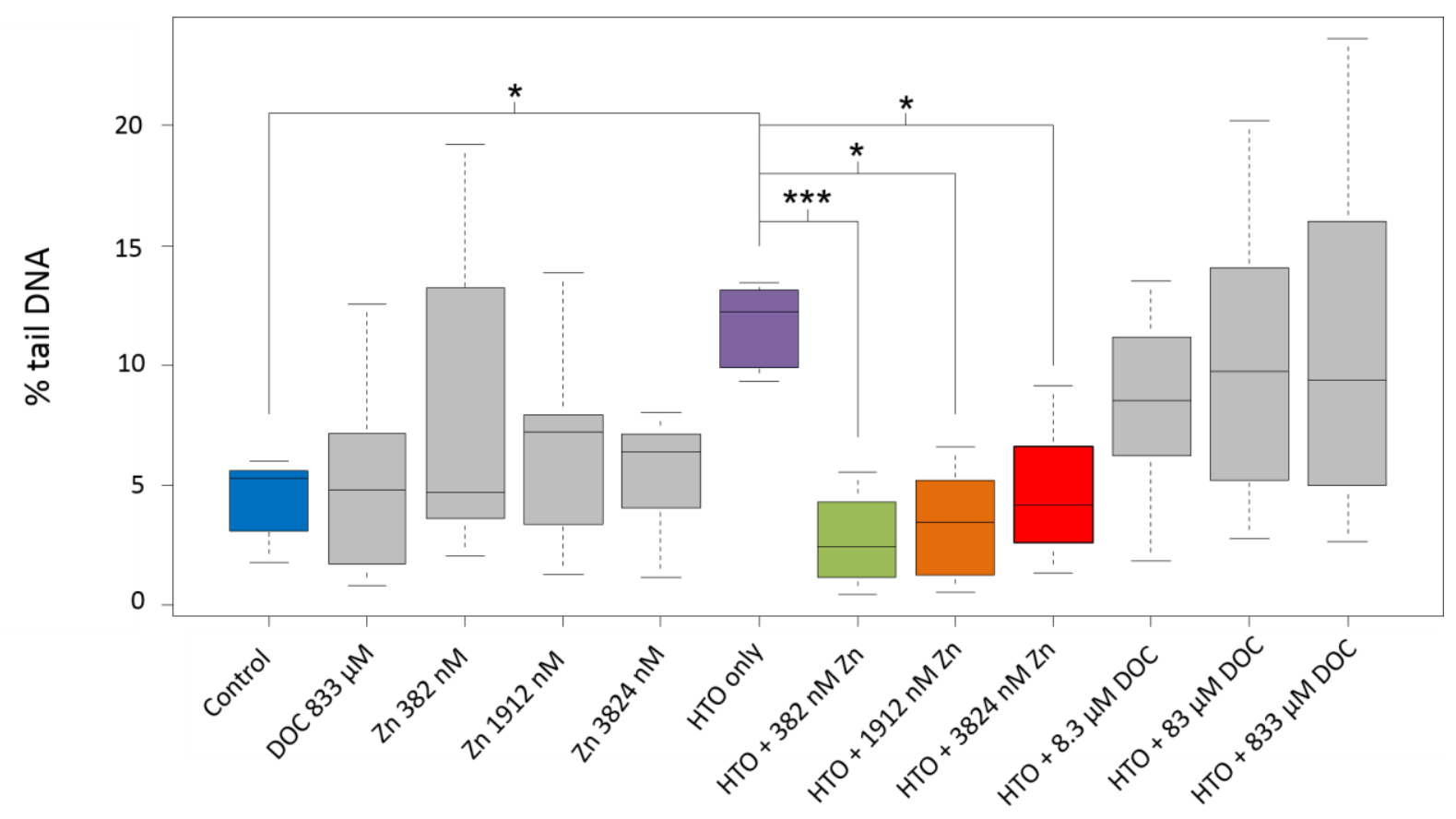

